\title{
GEOPHYSICAL AND GEOTECHNICAL FACTORS IN URBAN PLANNING: BURSA (NILÜFER, OSMANGAZİ, AND YILDIRIM) CASES
}

\author{
Ferhat Özçep ${ }^{1 *}$, Guldane Boyraz ${ }^{2}$, \\ Okan Tezel ${ }^{1}$, Hakan Alp ${ }^{1}$, Nuray Alpaslan ${ }^{3}$, Savaş Karabulut ${ }^{4}$ \\ 1* Correspounding Author, İstanbul University-Cerrahpasa, Department of \\ Geophysics, Buyukcekmece Istanbul, E mail: ferozcep@istanbul.edu.tr \\ 2 Istanbul University, Institute of Graduate Studies, Beyazit Istanbul \\ 3 Batman University, Department of Civil Engineering, Batman Istanbul \\ 4 TMMOB Jeofizik Mühendisleri Odası, Istanbul Şubesi, Istanbul
}

\begin{abstract}
The study area covers the Central of Bursa, Osmangazi, Yildirim, Gürsü, Kestel and Nilüfer District boundaries in Bursa. The seismic process deals with the occurrence of an earthquake event and the process of wave propagation from the source to the site. Local amplification caused by surficial soft soils is a significant factor in destructive earthquake motion. In the first phase of this study, it is investigated the ground motion level and soil amplifications for Bursa city. For his aim, probabilistic and deterministic earthquake hazard analysis (including acceleration estimations) will be carried out for the region. Local amplification caused by surficial soft soils is a significant factor in destructive earthquake motion. In the first phase of this study, it is investigated the ground motion level and soil acharacterization for the region. For his aim, probabilistic earthquake hazard analysis (including acceleration estimations) was carried out for the region. Then, soil shear wave velocities were estimated from data obtained by MASW measurements. Soil liquefaction is a natural event in which the strength and stiffness of a soil are reduced by earthquake vibrations or other dynamic loadings. As it is known, liquefaction occurs in saturated soils, that is, soils in which the space between individual particles is completely filled with water. One of liquefaction evaluation methods is based on the cyclic stress approach. In this method, a safety factor is defined as CRR / CSR. CRR is a cyclic resistance ratio that represents soil liquefaction susceptibility, and CSR is the cyclic stress ratio that represents the earthquake effect. In the second phase of this study, possible soil potential index (PL) and ground induced settlements were estimated by using Isihara ve Yoshimine (1990) approach. All results on liquefaction potential index $\left(\mathrm{P}_{1}\right)$, liquefaction induced settlements and soil shear wave velocities in Bursa (Turkey) City were
\end{abstract}


compared with each other. Finally, a seismic microzonation map was prepared by the integration of geophysical and geotechnical data for urban planning purposes.

\section{INTRODUCTION}

The vast majority of seismic microzonation studies have been carried out in earthquake-prone areas around the world (Marcellini et al., 1982, 1998; Astroza and Monge, 1991; Lasterico and Monge, 1972; Faccioli et al., 1991; Chavez-Garcia and Cuenca, 1998; Lungu and et al., 2000; Faccioli and Pessina, 2001; Fah et al., 1997). In terms of countries, Italy (Marcellini et al., 1998); Spain (Jimenez et al., 2000), Greece (Lachet et al., 1996) and Japan (Abeki et al., 1995) can be given as examples.

The first micro-zoning study in Turkey was conducted by the Construction and Housing Ministry and Earthquake Research Department in 1968. In this study, geological, geophysical and is used as an all geotechnical data and its first land-use planning as reflected in the physical planning of a city or in other words for estimation of local earthquake risk in Turkey. This city is the town of Kuyucak in Aydın province (Gülkan ve Ergünay, 2002, Kozac1 ve diğ., 1969). Later, microzonation study was made for the town of Gediz (Kozac1, 1970; Ergünay, 1971; Tabban, 1972, Tokay and Doyuran, 1978). Similar studies were carried out for Adapazarı in 1970, for Izmit in 1974, and cities such as Bolu, Gerede, and Erzincan. Erdik et al. (2000) carried out a microzonation study of İzmir city in the context of earthquake master plan. The first microzonation work with international partners was initiated under the name of "Disaster Prevention / Mitigation Including Istanbul City Seismic Microzonation" following the agreement signed between Istanbul Metropolitan Municipality and JICA (Japan International Cooperation Agency). If we take a look at the academic studies carried out within the scope of microzonation in our country, it seems that some articles on this subject were made by Ergünay (1973), Özçep et al. (2003) and Yılmaz et al. (2003).

The plan is the process to achieve a goal and perform a job with the simplest expression. Planning, on the other hand, is an act of planning and can be defined as a means of rational use of resources, a correct and rational decision-making process for the future to reach the expected goals. The most important goal of today's city/region planning is to provide people 
with a healthy and safe life. Regional planning can be defined as multidimensional planning, which is carried out by considering the mutual effects of the natural and artificial physical environment and economic and social activities to achieve the goals adopted by the community in urban areas (Aydemir, 1999, Özçep, 2005; Özçep ve diğ., 2003).

In this study, Multi-Channel Analysis of Surface Wave (MASW) analysis measurements were made at 100 points carried out to obtain shear wave velocities (Vs) in the site-effect investigation. Using MASW, shear wave velocity was obtained at 100 points up to 50 meters deep from the surface. As is known, MASW is derived from the classical seismic search method based on the multi-receiver system lined up along a line. Its main advantage is its ability to recognize different types of seismic waves. This technique is important in obtaining the shear wave velocity (Park et al., 1999; Park et al., 2007). Uniform Building Code, Eurocode, etc). With this method, both active and passive source measurements were made and both measurement results were evaluated together.

The first task for soil liquefaction analysis is to determine the ground motion level for the selected region. After earthquake hazard analysis for the region is undertaken, in the second stage of the study, soil liquefaction and settlements for the selected region were calculated for various earthquake accelerations and magnitudes.

\section{IMPORTANCE OF GEOTECHNICAL ANF GEOPHYSICAL FACTORS}

One of the first known settlements of the world with its urban character and structure is Çatalhöyük located in Anatolian lands (Shane III and Küçük, 1998). Interestingly, the relationship between this city (where the first urban planning was made) and natural disasters was reflected in the art of the period. A wall painting from $6500 \mathrm{BC}$ in Çatalhöyük can be seen in Figure 1. Here, an active volcano and city plan were drawn together. This picture is probably the oldest known geophysical figure in the world. The active volcano in the picture is thought to be Hasandağ

The most important goals of today's urban / regional planning and urban transformation planning are to provide people with a healthy and safe life. Regional planning can be defined 
104 as multi-dimensional planning, which is carried out by considering the mutual effects of the

105 natural and artificial physical environment and economic and social activities to achieve the goals adopted by the community in urban areas. Two different factors play a role in planning studies. The first factor is needed to be taken under control of the big cities emerging as a result of industrialization. The second factor is to develop the underdeveloped regions of a country and to use natural resources that are not evaluated effectively. These are driving force of planning studies (Aydemir, 1999, Özçep, 2005; Özçep et al., 2003; Özçep and Zarif, 2006, Korkmaz and Özçep, 2020, Özçep et al, 2020).

2

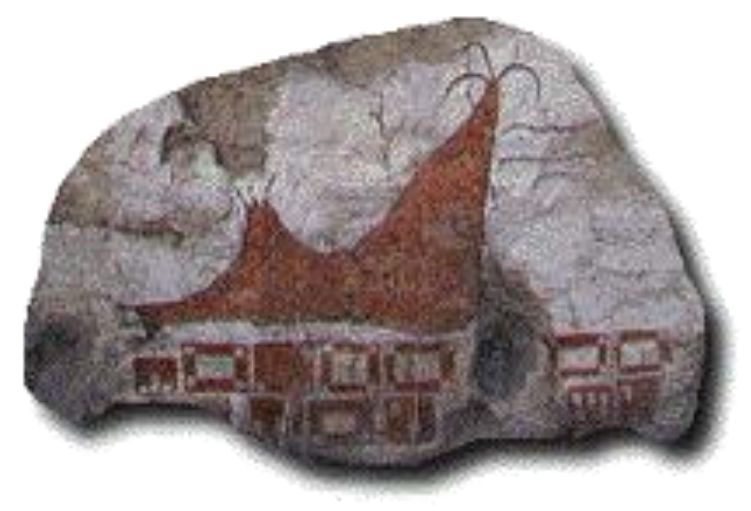

Figure 1. A wall painting from 6500 BC in Çatalhöyük (Anatolian Civilizations Museum, Ankara)

Vast social changes and dramatic growth of the urban population led to the need for improvement / development of urban areas to meet new demands. In this context, urban transformation and microzonation studies were carried out in many large and small settlements of the country with city or metropolitan status. Urban transformation can be defined as multidisciplinary studies created to serve the improvement of unqualified and suburb regions for a legal and healthy life in the border regions of industrial cities receiving immigration (Nalkaya, 2006). Not only regions with historic texture or slum areas but also regions under threat from earthquakes and other natural disasters should be evaluated within the scope of these urban transformation studies. It should be noted that while factors such as 


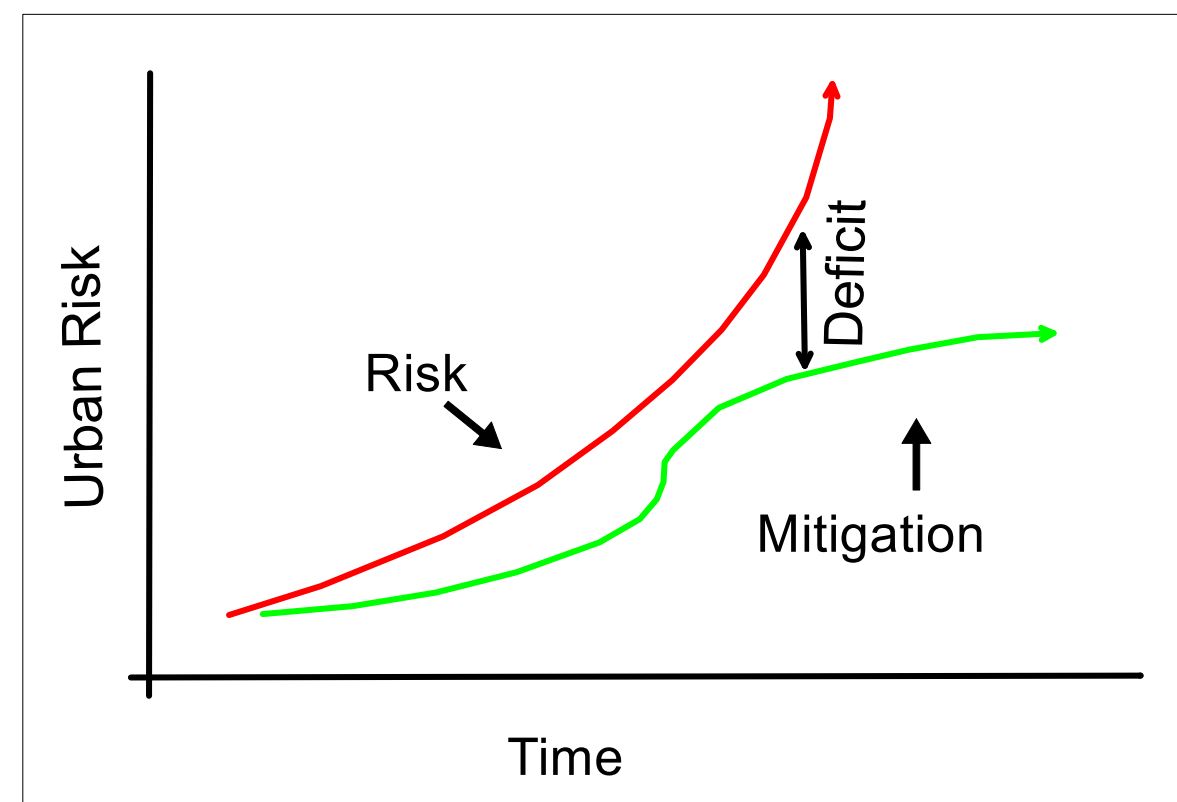

Figure 2. Urban Risk-Time Relationship (Wenzel and Bendimerad, 2004 )

From a general perspective, risk is defined by Beck (1999) as "human actions caused by the unplanned consequences of radicalized modernization". According to Beck, we are members of the world risk community. Risk is a result of the impact of modern technologies. Risk has globalized and overcomes the power of the national state, and the modern age has entered a new phase called Beck's "second modernity". The "risk society" view is defined as a state of radicalized modernity. Beck divides modern society into three periods: pre-industry, industry period and global risk society. The downside of globalization is that economic expansion and technological risks are beyond our control. According to Beck, this should be reacted with a unique form of globalization: Cross-border alliances and global networks should be established to tackle global problems on a global level. Only then can you have the chance to turn "world risk society" into "world citizenship society" as Kant says.

147 The factors that create the risk society by Beck (1992) are defined as 
148

149

150

151

152

153

154

155

156

157

158

159

160

161

162

163

164

165

166

167

168

169

170

171
- After the modern, consumption of nature / society / individual and transform them into risks

- As science and technology are out of democratic control

If we take a look at one of the most important natural risks (earthquakes), an average of 700 damage-causing earthquakes occur annually around the world. Earthquakes occurring in urban areas are among the most devastating natural disasters.

140,000 people died in the 1923 Kanto (Japan) earthquake and 240,000 people in the 1976 Tangshan (China) earthquake, and the total losses in the 1995 Kobe (Japan) earthquake exceeded 200 billion dollars. Although it is not yet possible to predict earthquakes, studies in this direction continue using all the possibilities of science and technology. On the other hand, it is possible to reduce the material losses and socio-economic losses that will occur as a result of earthquakes to reasonable levels by taking measures against earthquake damages. In this regard, the city's local administrators have important duties in urban planning, land use and control of buildings.

The intense and direct relationships of local administrators with the people of the city make it possible to transfer information about earthquake damage reduction and to raise the awareness of the public against earthquakes in general (Erdik et al., 2000). Düzgün (2006) proposed a model to determine the spatial vulnerability of an urban area to the earthquake disaster in terms of various factors (accessibility to structure, soil, social, economic, administrative and critical services) using a selected city area as a pilot application area (Figure 3). 


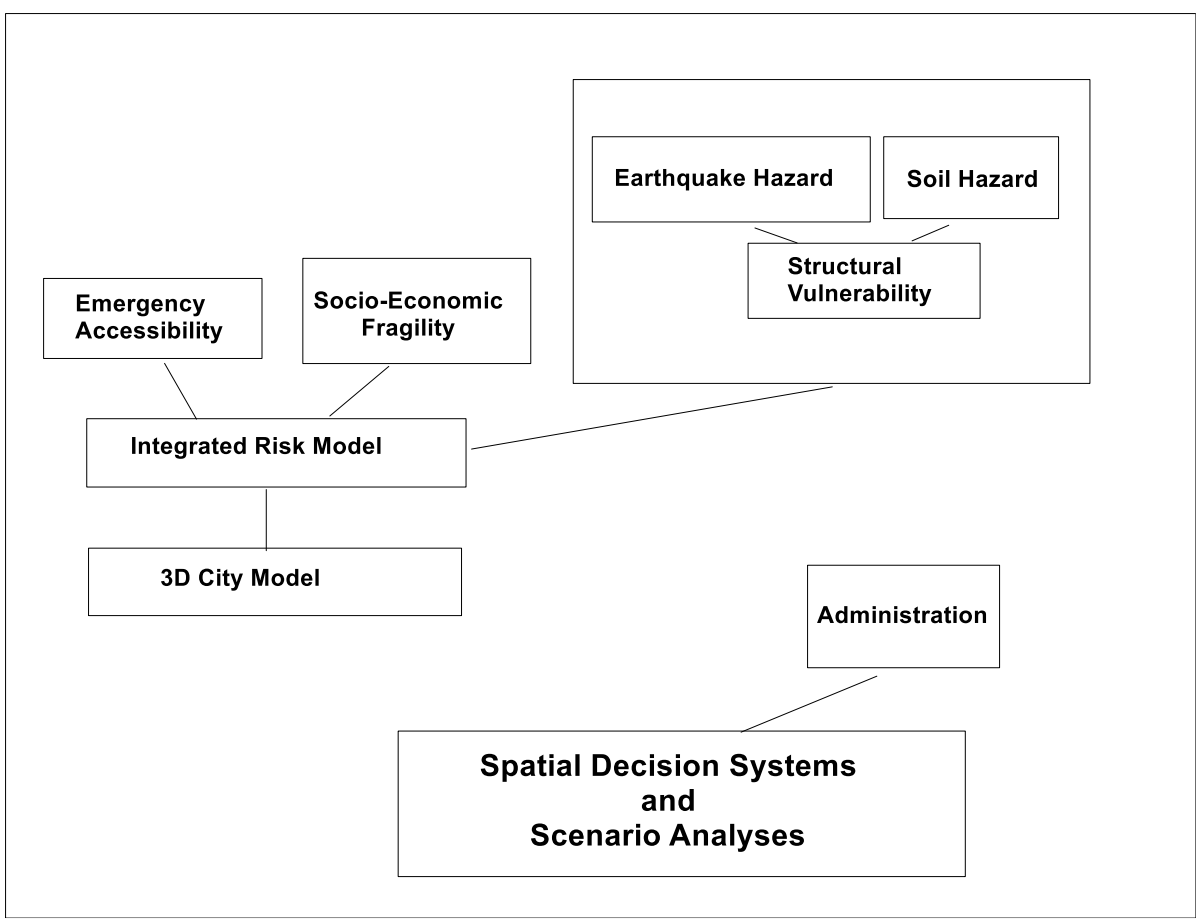

Figure 3. Spatial vulnerability model in terms of various factors (accessibility to structure, earthquake, soils, social, economic, administrative and critical services) to the earthquake disaster of the urban area using a selected urban area as a pilot application area (Düzgün, 2006).

Necessary items to estimate the effects of earthquakes in urban areas are historical earthquake information, geological, geophysical and geotechnical data, probabilistic or deterministic evaluation of earthquake hazard, determination of ground motion according to soil conditions and preparation of these studies in the context of microzonation studies.

Urban planning became prominent as an important study in expanding urban areas as a result of population growth. The balance between human settlements and the natural environment is disrupted by urbanization (De Mulder, 1996). Urban planning practices must reduce these conflicts / imbalances to improve the general well-being and quality of life of society (Bell, 
1998; Bell et al., 1987). Such planning must be in a multi-disciplinary approach for various human needs (De Mulder, 1996). However, geological, geophysical and geotechnical data in urban planning have become increasingly important in identifying, controlling and mitigating natural disasters (Bell et al., 1987; Legget, 1987; Hake, 1987).

Many earthquakes in the past and present have shown that local soil conditions (including topography effects) have a major impact on damage distribution. When earthquake hazard is evaluated on a regional or local scale, it is very important to identify and take into account these possible local site effects. Seismic microzonation has been an economically useful element of the earthquake risk reduction process (Roca and Oliviera, 2001). Microzonation against earthquake hazards has been defined as the division of a geographical region into small areas according to the behavior of the soils underground motion or slope stability (Hays, 1980; Sharma and Kovacs,1980)

Nigg (1982) stated that microzonation aims to divide the risky areas into small pieces in order to implement the right plans and policies that can minimize the damage that may occur after the earthquake. Finn (1991) has defined microzonation as procedures involving the development of measures for seismic hazards for building design, taking into account local soil conditions.

In 1993, a guideline study describing the principles was made on microzonation for "soil amplification", "slope stability" and "liquefaction" by the Earthquake Geotechnical Engineering Committee of the International Soil Mechanics and Foundation Engineering" (later "Geotechnical Engineering") Union (ISSMFE, 1993). (ISSMFE, 1993). This work was revised in 1999 (ISSMGE / TC4 1999).

During earthquakes, seismic waves, especially under the effect of shear waves, spread in loose soils that are generally saturated and without drainage, creating shear forces relative to each other, causing soil particles to displace. Under these conditions, saturated and loose soil particles tend to converge on each other. The stress at the contact points of the particles in this case is transmitted to the surrounding water. Since the seismic waves cause sudden and very short movements during the earthquake, it does not allow sufficient time for the water between the particles to drain. Therefore, the pressure of pore water, which cannot move away 
from the environment, increases suddenly. This sudden increase in pore water removes the contact forces that hold the soil particles together and removes the particles from each other. Thus, the soil loses its strength. Under these conditions, where the effective vertical pressure is zero, the soil acts as a liquid instead of a solid. This behaviour, which the soil presents as a result of dynamic loads, is known as liquefaction.

Both soil amplification and soil liquefaction developing on the soils due to earthquake effects are critical studies for microzonation studies of urban areas.

\section{GEOLOGY TECTONICS OF THE REGION}

The study area covers the central districts of Bursa province. These districts are connected to Bursa Metropolitan Municipality; Osmangazi, Kestel, Yıldırım, and Kestel districts. Regarding the historical earthquake records, the district has a remarkable feature as it is located in an area with high earthquake potential. The geology of the study area was prepared by Zetaş (2000). It is located in an ellipsoidal basin, known as the Bursa basin, which started its formation in the Neogene and continued during the Quaternary period and is in the direction of D-B. This basin is one of Turkey's major tectonic structures, formed in the effect of the North Anatolian Fault Zone. The main faults surrounding the study area are given in Figure 4.

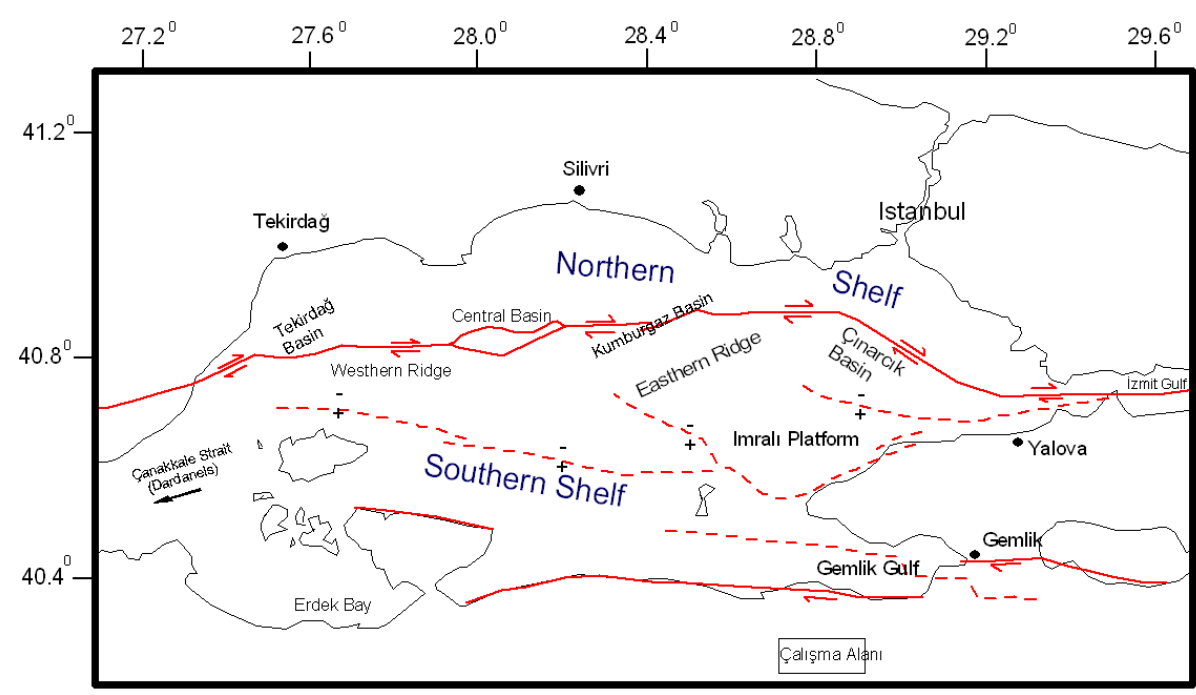


Figure 4. Main faults surrounding the study area (Le Pichon et al., 2001, Redrawn)

Karakaya group rocks outcrop in the south and southeast of the study area, where the oldbased (paleozoic) relationship cannot be seen. The conglomerate, micro conglomerate, sandstone, feldspar sandstone, micaceous sandstone, grovak, claystone, basic volcanic and limestone alternation are observed. It also contains a large amount of limestone (Permian) olistoliths in various sizes. It contains radiolarite, diabase and spilitic intermediate (Zetaş, 2000). Alluvium: Bursa plain, which is a tectonic depression basin, is completely carried by rivers; blocks with detritic material such as gravel, sand, and silt. Alluvium thickness varies between $80 \mathrm{~m}-200 \mathrm{~m}$. In the central part of the Bursa plain, the alluvium thickness varies between $140 \mathrm{~m}-200 \mathrm{~m}$. It consists of clay with fine elements, silt, sand, and gravel. It is difficult to separate alluvium and Neogene units (Zetaş, 2000).

In order to explain the current features of the Marmara region, it is necessary to mention plate tectonic movement of Turkey and the surrounding area. Turkey is located on a mountain formation system we call the Alpine-Himalayan Belt (Ketin, 1977). Crustal movement occurs in the Turkish plate due to the young and active tectonics as a result of $(2.0-2.5 \mathrm{~cm})$ northward of the Arabian Peninsula.

\section{GEOTECHNICAL AND GEOPHYSICAL ANALYSES FOR REGION \\ For geophysical and geotechnical characterization, the view of the measurement points taken within the boundaries of the district is given in Figure 5a and $b$.}




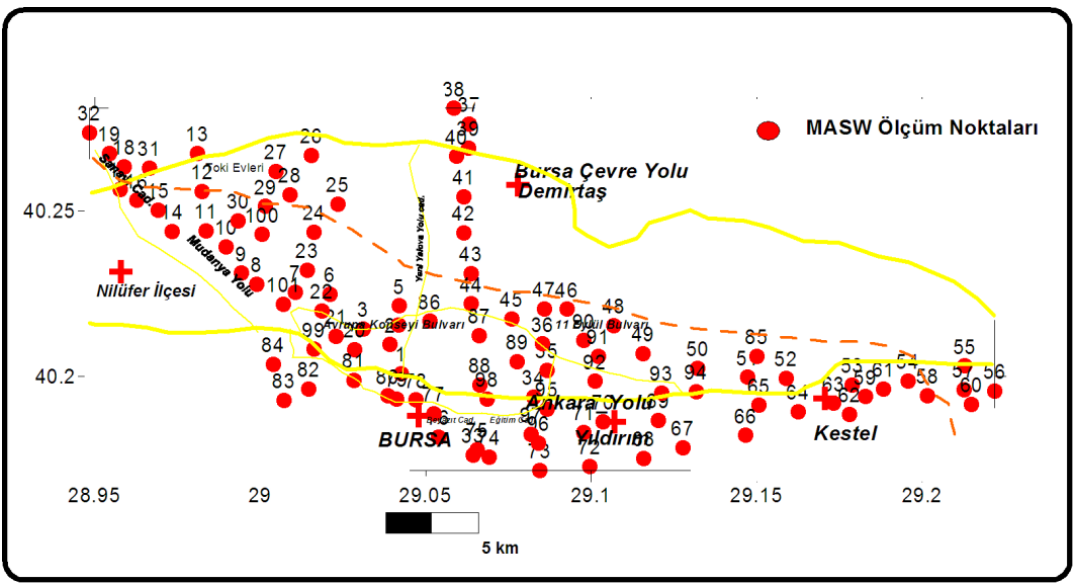

Figure 5a. Location of the study area Geophysical (MASW) measurement points at Osmangazi ve Yıldırım

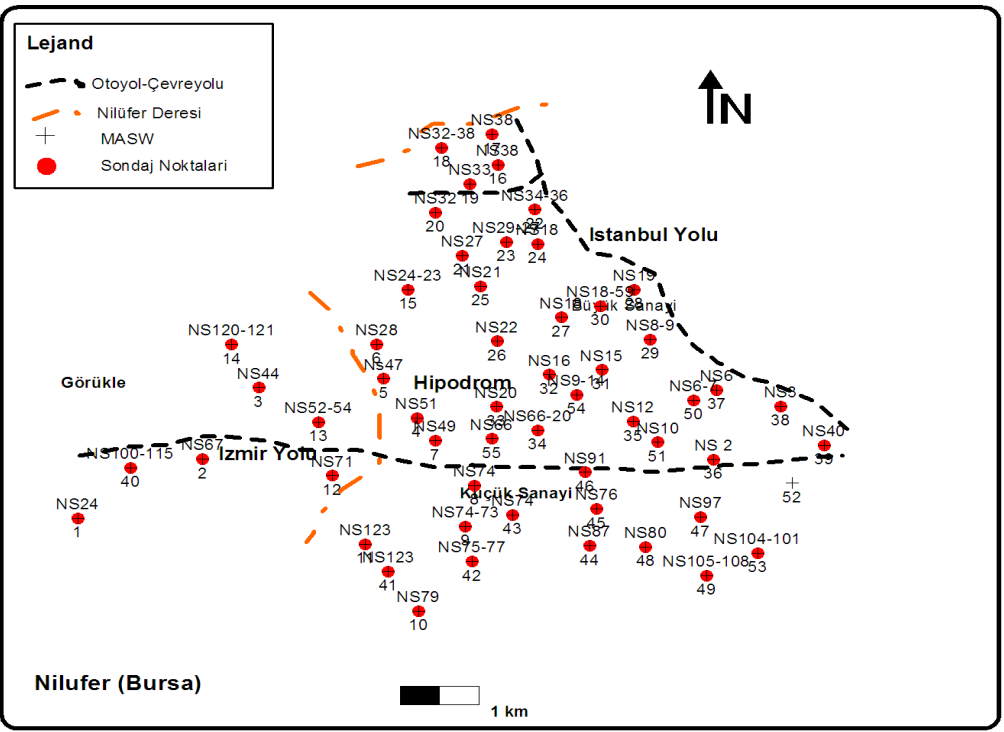

Figure 5b. Location of the study area and boreholes and the Geophysical (MASW) measurement points at Nilüfer District

\subsection{Geophysical Factors}

There are several geophysical measurements and evaluations used in field or site investigations. In this context, geophysical measurements can be divided into two groups as 
exploration geophysics methods and engineering seismology studies. The most important exploration geophysics methods are seismic methods that are the main method to estimate Vs velocity. Engineering eeismology studies include evaluating probalistic and deterministic seismic hazards to estimate the ground motion level.

\subsubsection{Seismic Hazard Analysis of the Region}

Turkey is a region where there are interactions of Arab-Africa plates in the south and Eurasian plate in the North. Many important fault zones are effective within Turkey. The closest fault zone that will affect the study area is the North Anatolian fault zone. The approximate length of this fault zone is around $1200 \mathrm{~km}$. In recent years, the city of Erzincan in eastern Turkey has seen very severe earthquakes (1939 and 1992). While more than 30.000 people died in the 1939 earthquake, 700 people died in 1992. With the collapse of several buildings and infrastructure, a high rate of property loss was observed. On August 17, 1999, an earthquake disaster called Kocaeli earthquake occurred around Izmit and Adapazar1, $110 \mathrm{~km}$ east of Istanbul. This earthquake, the magnitude of which was estimated to be between 7.4 and 7.6 by various researchers, damaged human life and property at a very high rate in the region. Another magnitude 7.2 earthquake occurred on November 12, 1999, in the northern Anatolian fault zone. Over a thousand people were dead or seriously injured. There are some estimations that the centres of these strong earthquakes are shifting from east to west along the North Anatolian Fault zone and draw attention to the possibility that a major earthquake could shake Istanbul, located at the western end of the North Anatolian Fault.

\section{Probabilistic Earthquake Hazard Analysis for the region}

The probabilistic earthquake hazard is defined as the probability that the damaging ground motion will occur in a certain place and within a certain period of time. For the analysis, it was obtained 4.5 and larger earthquakes during the instrumental period within an area of 100 $\mathrm{km}$ radius, focusing on the region from a database of Kandilli Observatory and Earthquake Research Institute. Earthquake hazard analysis was carried out using "SoilEngineering" software developed by Ozcep (2010). The results of this analysis are given in Figure 6 and in Table 1.a, 1.b, 1.c. 


\begin{tabular}{|l|c|c|c|c|c|}
\hline \multicolumn{2}{|c|}{ Year Interval } & \multicolumn{3}{c|}{} \\
\hline Magnitude Range & $\mathbf{4 . 5} \leq \mathbf{M}<\mathbf{5 . 0}$ & $\mathbf{5 . 0} \leq \mathbf{M}<\mathbf{5 . 5}$ & $\mathbf{5 . 5} \leq \mathbf{M}<\mathbf{6 . 0}$ & $\mathbf{6 . 0} \leq \mathbf{M}<\mathbf{6 . 5}$ & $\mathbf{7 . 0} \leq \mathbf{M}<7.5$ \\
\hline Ni (Frequency) & $\mathbf{4 7}$ & $\mathbf{2 1}$ & $\mathbf{1 1}$ & $\mathbf{4}$ & $\mathbf{1}$ \\
\hline $\begin{array}{l}\text { Mean Magnitude M } \\
\text { or (Xi) }\end{array}$ & 4,7 & 5,2 & 5,7 & 6,2 & 7,2 \\
\hline
\end{tabular}

\begin{tabular}{|c|c|}
\hline .a & 3,02 \\
\hline b & $-0,66$ \\
\hline
\end{tabular}

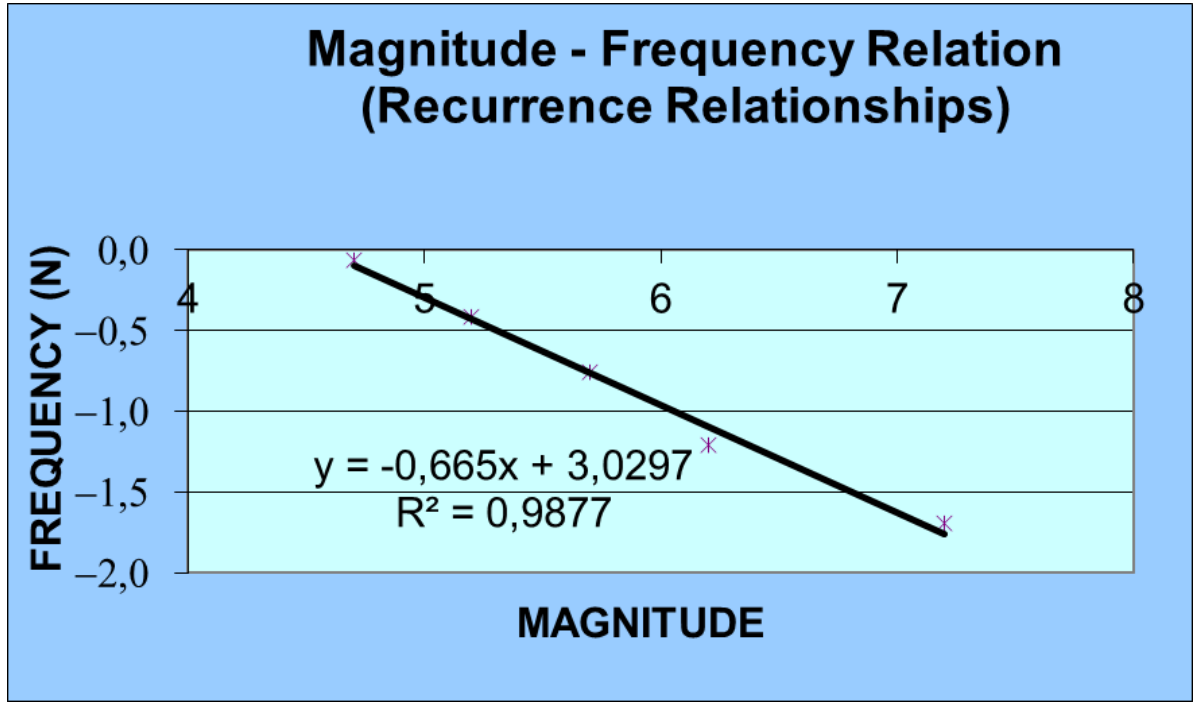

Figure 6. Magnitude - Frequency Relationship for Poison probability model

\section{Tablo 1.b Earthquake probability for various years and magnitudes estimated by Poison} Probability distribution

\begin{tabular}{|c|c|c|c|c|c|}
\hline Magnitud & $\begin{array}{c}\mathrm{D}= \\
\text { Probability } \\
\text { for 10 years } \\
(\%)\end{array}$ & $\begin{array}{c}\mathrm{D}= \\
\text { Probability } \\
\text { for 50 } \\
\text { years }(\%)\end{array}$ & $\begin{array}{c}\mathrm{D}= \\
\text { Probability } \\
\text { for 75 years } \\
(\%)\end{array}$ & $\begin{array}{c}\mathrm{D}=\text { Probability } \\
\text { for 100 years } \\
(\%)\end{array}$ & $\begin{array}{c}\text { Recurrence Period } \\
(\text { Year })\end{array}$ \\
\hline 5 & $\mathbf{9 9 . 4}$ & $\mathbf{1 0 0 . 0}$ & $\mathbf{1 0 0 . 0}$ & $\mathbf{1 0 0 . 0}$ & $\mathbf{2}$ \\
\hline 5.5 & $\mathbf{8 7 . 8}$ & $\mathbf{1 0 0 . 0}$ & $\mathbf{1 0 0 . 0}$ & 100.0 & $\mathbf{5}$ \\
\hline 6 & $\mathbf{5 7 . 4}$ & $\mathbf{9 8 . 6}$ & $\mathbf{9 9 . 8}$ & 100.0 & 12 \\
\hline 6.5 & $\mathbf{2 9 . 3}$ & $\mathbf{8 2 . 3}$ & $\mathbf{9 2 . 6}$ & $\mathbf{9 6 . 9}$ & $\mathbf{2 9}$ \\
\hline 7 & $\mathbf{1 3 . 1}$ & $\mathbf{5 0 . 5}$ & $\mathbf{6 5 . 2}$ & $\mathbf{7 5 . 5}$ & $\mathbf{7 1}$ \\
\hline 7.6 & $\mathbf{4 . 7}$ & $\mathbf{2 1 . 2}$ & $\mathbf{3 0 . 0}$ & $\mathbf{3 7 . 9}$ & $\mathbf{2 1 0}$ \\
\hline
\end{tabular}




\begin{tabular}{|c|c|c|}
\hline D (year) & Probability of Exceedance (\%) & M (magnitude) \\
\hline 50 & 30 & 7,4 \\
\hline
\end{tabular}

\begin{tabular}{|c|c|c|c|c|c|}
\hline & \multicolumn{2}{|c|}{$\begin{array}{c}\Delta, \text { Epicentral Distance } \\
(\mathrm{km})\end{array}$} & $\begin{array}{l}\text { H, Focal } \\
\text { depth }(\mathrm{km})\end{array}$ & & \\
\hline & \multicolumn{2}{|c|}{25} & 15 & & \\
\hline Researcher & $\begin{array}{c}\text { Donavan(197 } \\
\text { 3c) }\end{array}$ & $\begin{array}{r}\text { Olivier } \\
(1974) \\
\end{array}$ & $\begin{array}{c}\text { Joyner ve } \\
\text { Boore (1981) } \\
\end{array}$ & $\begin{array}{c}\text { Campbell } \\
(1997)\end{array}$ & Average \\
\hline $\begin{array}{l}\text { Acceleration } \\
\text { (a) }\end{array}$ & 0.23 & 0.16 & 0.39 & 0.42 & 0.30 \\
\hline
\end{tabular}

343

\section{Geophysical Analysis based on Field Studies}

345 Within the coverage of this study, geophysical study (surface wave analysis (MASW) and 346 shear wave velocity estimation) was carried out at 100 different points in the districts of Bursa 347 Metropolitan Municipality. The average shear wave velocity (Vs30) map for the 30 meters 348 obtained as a result of the measurement is given in Figure 7 for Osmangazi district and its 349 surroundings (Region 1) and Figure 8. (for Nilüfer District (Region 2), soil fundamental period and soil amplification maps were given in Figure 9a, b, c, d, e. Some locations of the study area are not suitable to acquired geophysical data especially central parts of Osmangazi district and its surrounding area. 


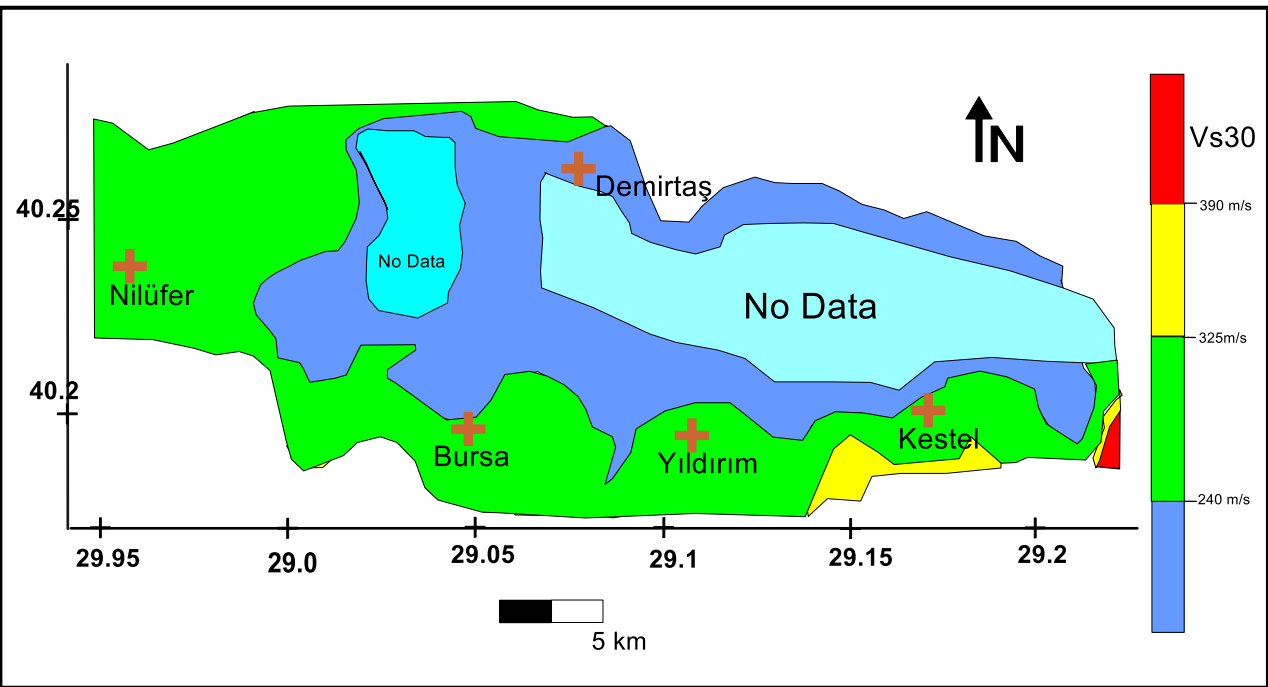

Figure 7. Bursa (Osmangazi, Yildirim, Gürsü, Kestel) Districts and VS30 map of Soils and measurement locations (black dots with numbers ) acquired on the Osmangazi district.

It was observed there were three different velocity zones from the Vs30 distribution map of Osmangazi district and its surroundings (Fig. 7). On the basis of Vs 30 values of the study area can be classified as high $(380 \mathrm{~m} / \mathrm{sn}-450 \mathrm{~m} / \mathrm{sn})$, medium $(260-380 \mathrm{~m} / \mathrm{sn}-)$ and lower $(<$ 260). S wave values related to regional topography. While lower values correspond to the basin, high and medium $S$ wave values related to hill zones. The eastern part of Region 1, located in the part of the Nilüfer District, and in a narrow zone in the south of Region 1 have medium and higher shear - wave velocity values within the range $260 \mathrm{~m} / \mathrm{sn}-440 \mathrm{~m} / \mathrm{sn}$. The Vs 30 values are then decreasing to the west and to the north towards the central of Region 1. The Vs30 map in Region 1 shows very good agreement that low velocities in the centeral part correspond to alluvium in Bursa Plain. 


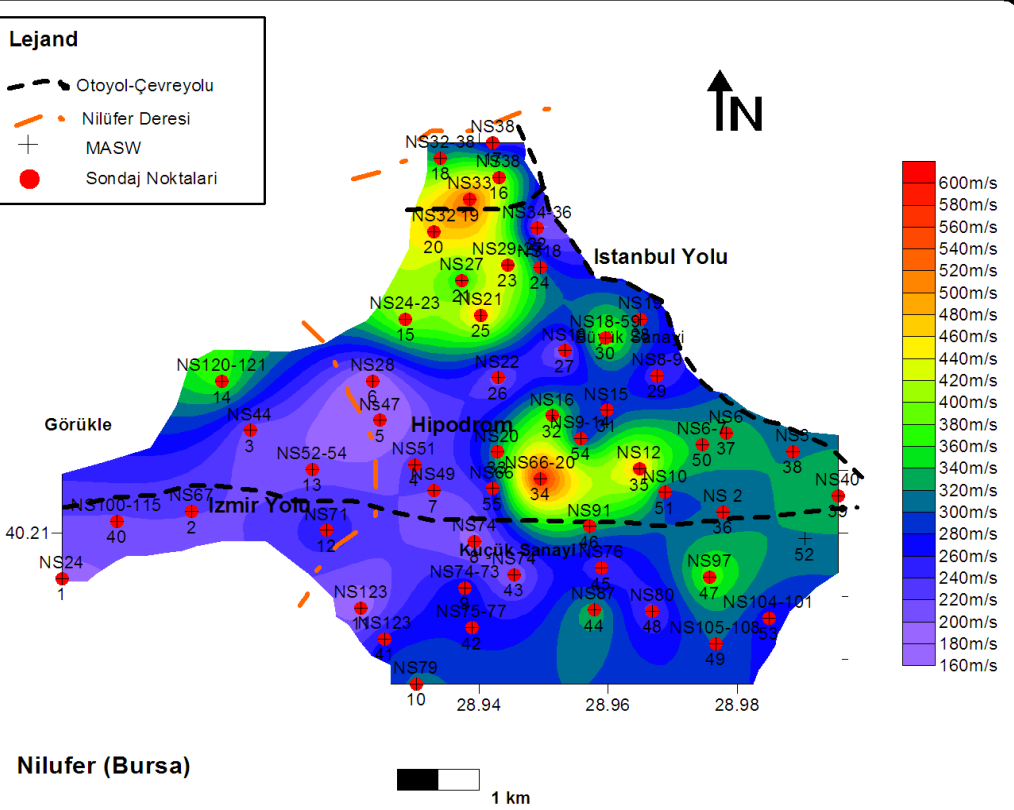

Figure 8. Bursa (Nilüfer) District and VS30 map of Soils

The Vs 30 distribution map of Region 2 shows three different velocity zones as Region 1. In contradistinction to, while higher velocity was obtained, ranging from $480-600 \mathrm{~m} / \mathrm{sn}$, medium velocity values within range $340-480 \mathrm{~m} / \mathrm{sn}$. In this region, only two local areas have high Vs velocities. While One of these local areas is the northern part of Region 2 that has 580m/sn shear velocity maximum, the other is the center of the region towards the east that has a maximum of $600 \mathrm{~m} / \mathrm{sn}$ higher Vs30 values. The lower Vs 30 velocities are calculated in all other areas. Lower values within range $160-280 \mathrm{~m} / \mathrm{sn}$. 


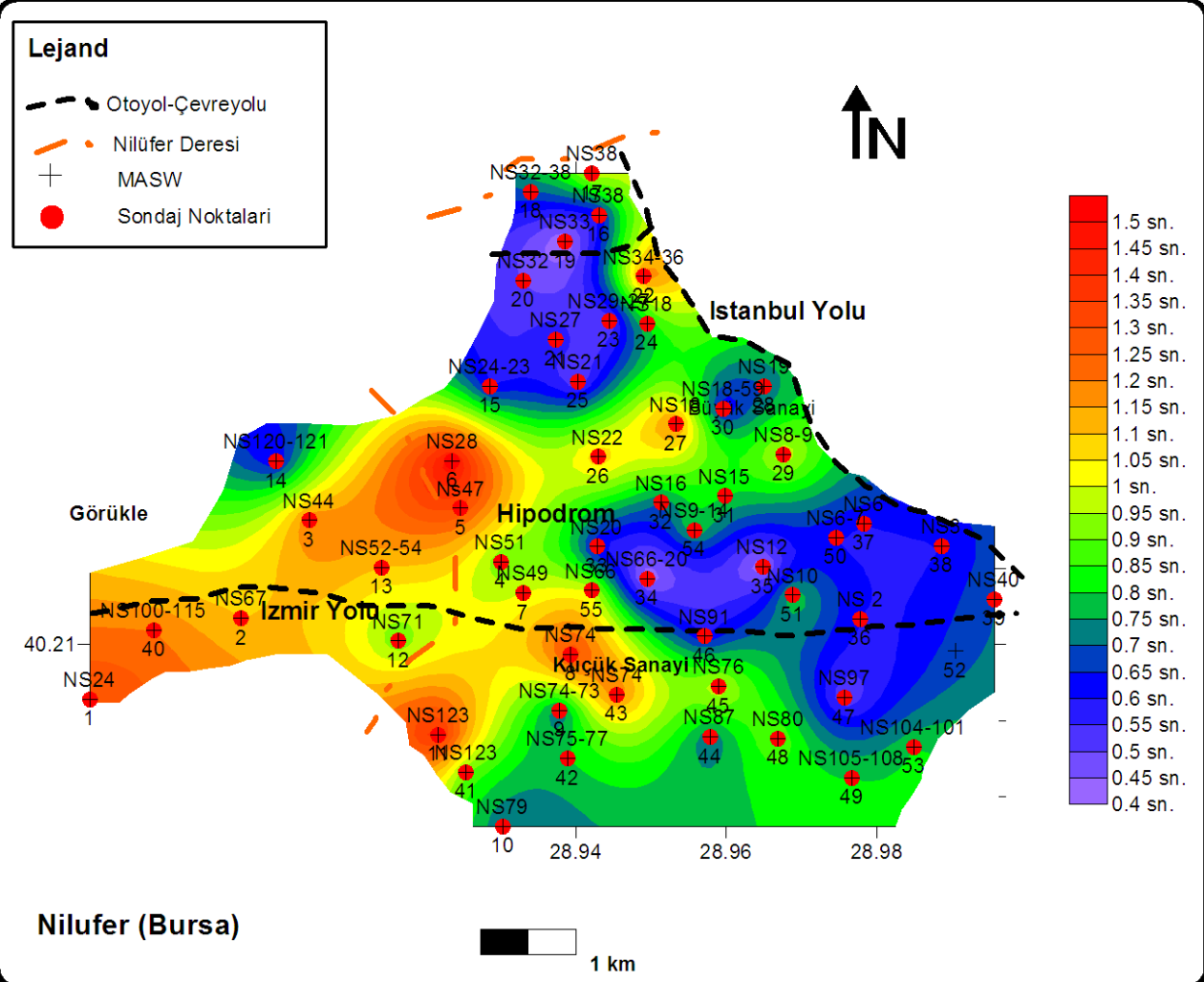

Figure 9a. Soil Fundamental Period Map in Nilüfer (Bursa) District

The contour map of the Soil Fundamental Period Map in Nilüfer (Bursa) District is computed from MASW and microtremor measurements. The fundamental period values of the sites located within areas with low Vs 30 seismic velocities are generally higher than areas with higher Vs 30 values. The soil fundamental period map in Nilüfer (Bursa) District, especially the lowest fundamental period values zones, coincides with the previous results of the Vs 30 distribution map. In the northern part of the area, the fundamental periods are computed between $0.4-0.7 \mathrm{sn}$, whereas at the sites in the allüvial basin, the values increase to $1.0-1.5 \mathrm{sn}$. In addition, low fundamental periods of 0.4.- $0.7 \mathrm{sn}$ are also observed in the eastern part of the area. 
https://doi.org/10.5194/nhess-2020-301

Preprint. Discussion started: 8 October 2020

(c) Author(s) 2020. CC BY 4.0 License.
Natural Hazards and Earth System Sciences

Discussions

Figure 9b. Soil amplification maps accordin to Midorikawa (1987) Approach in Nilüfer (Bursa) District

400

401
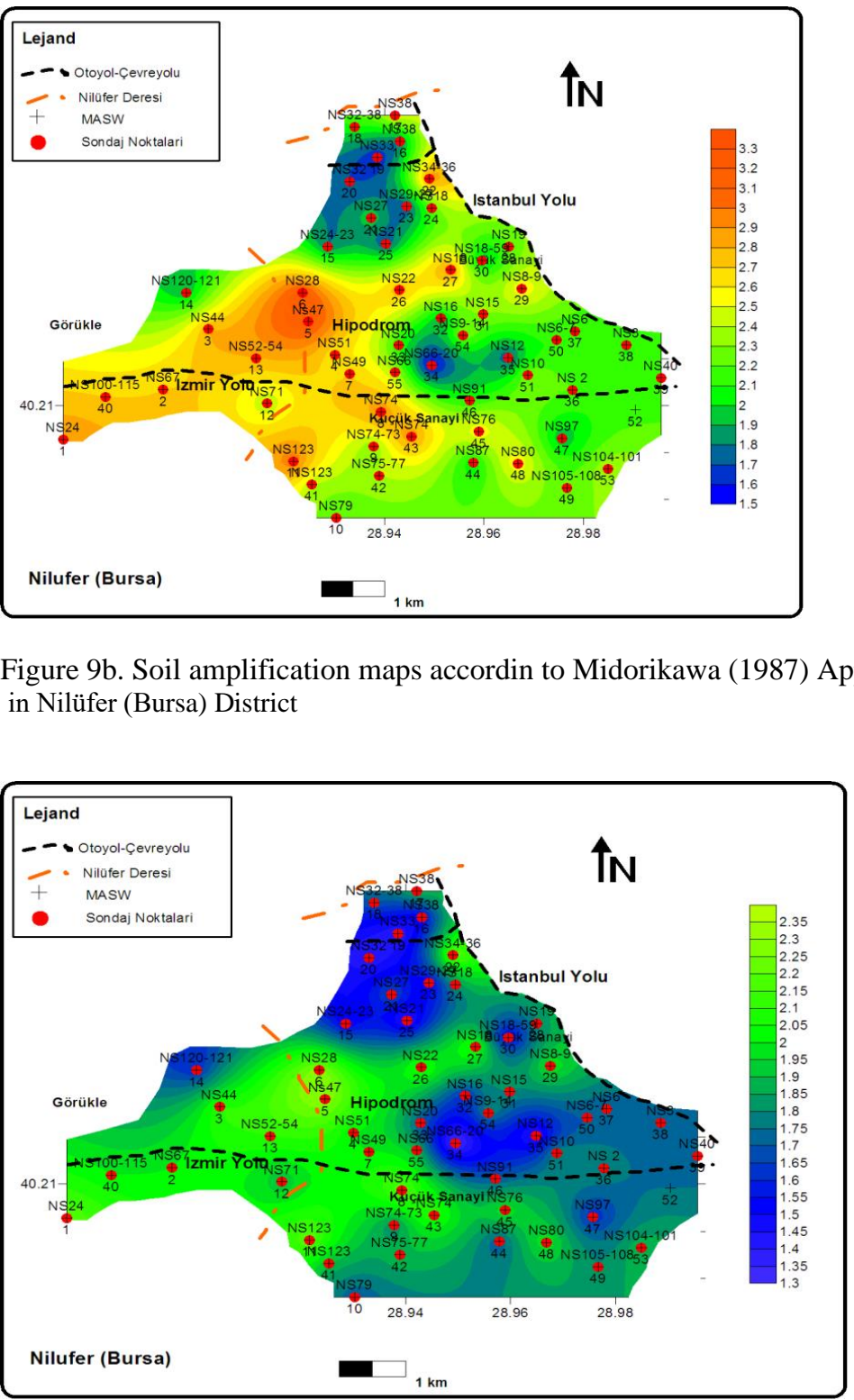

Figure 9c. Soil amplification maps according to Joyner and Fumal (1984) Approach in Nilüfer

$$
\text { (Bursa) District }
$$


https://doi.org/10.5194/nhess-2020-301

Preprint. Discussion started: 8 October 2020

(c) Author(s) 2020. CC BY 4.0 License.
Natural Hazards and Earth System Sciences

Discussions
407

408

409

410

411

412

413

414

415

416

417

418

419

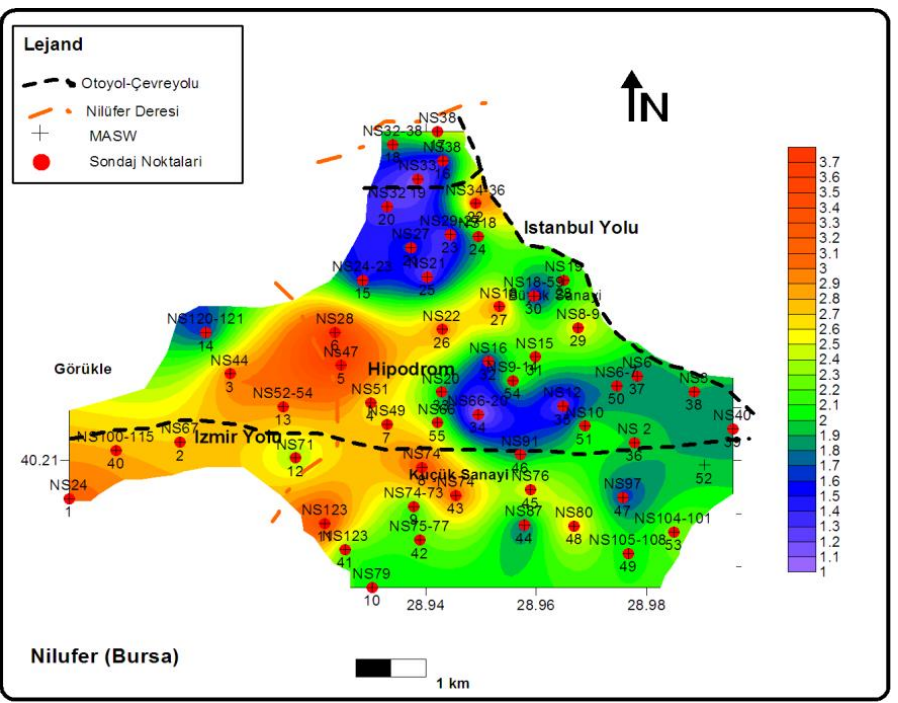

Figure 9d. Soil amplification maps according to Borcherdt et al (1991) approach for strong motion in Nilüfer (Bursa) District

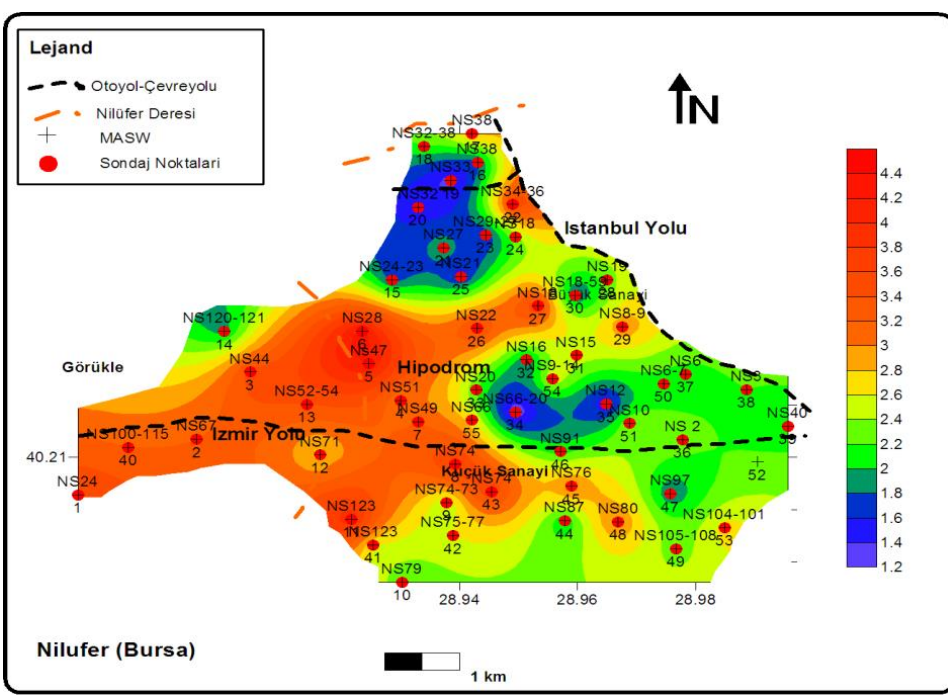

Figure 9e. Soil amplification maps according to Borcherdt et al (1991) approach for weak motion in Nilüfer (Bursa) District 
420 Figure 9d and e show comparisons between the soil amplification map according to various approaches (Joyner and Fumal (1984) ; Midorikawa (1987); Borcherdt et al (1991) for strong and weak motion) . According to the map obtained from Joyner and Furnal's (1984) approach (Fig. 9d), while high soil amplification values are observed at the western and central part of the study area, low values are observed at the northern and eastern part of the area. This approach is very well compatible with the Vs 30 map and the fundamental period map. The high values calculated from other approaches also coincides with previous results of geophysical investigations. If the approaches are compared to each other, maximum soil amplification values are calculated from Borcherdt et al (1991) approach for weak motion with these values ranging from 4.4 -3.0.

In other approaches, these maximum values within range 2.0- 3.7. According to Joyner and Furnal's (1984) approaches, soil amplification values are computed within the range of 1.3 2.35. These values are the minimum values in all approaches.

\section{Soil-Earthquake Interaction Maps}

Soil-earthquake interactive acceleration maps were made by taking into account Vs30 values obtained by surface wave velocity (MASW) analysis in Nilüfer District. The measurement points on the Vs30 perpendicular distance to the measurement points in the northern part is $15 \mathrm{~km}$, the measurement points in the central part are $20 \mathrm{~km}$ and the measurement points in the south are $25 \mathrm{~km}$ and the size chosen for the design is M: 7.6. Boore et al. (1997) spectral acceleration map was made with 
https://doi.org/10.5194/nhess-2020-301

Preprint. Discussion started: 8 October 2020

(c) Author(s) 2020. CC BY 4.0 License.
Natural Hazards and Earth System Sciences

Discussions

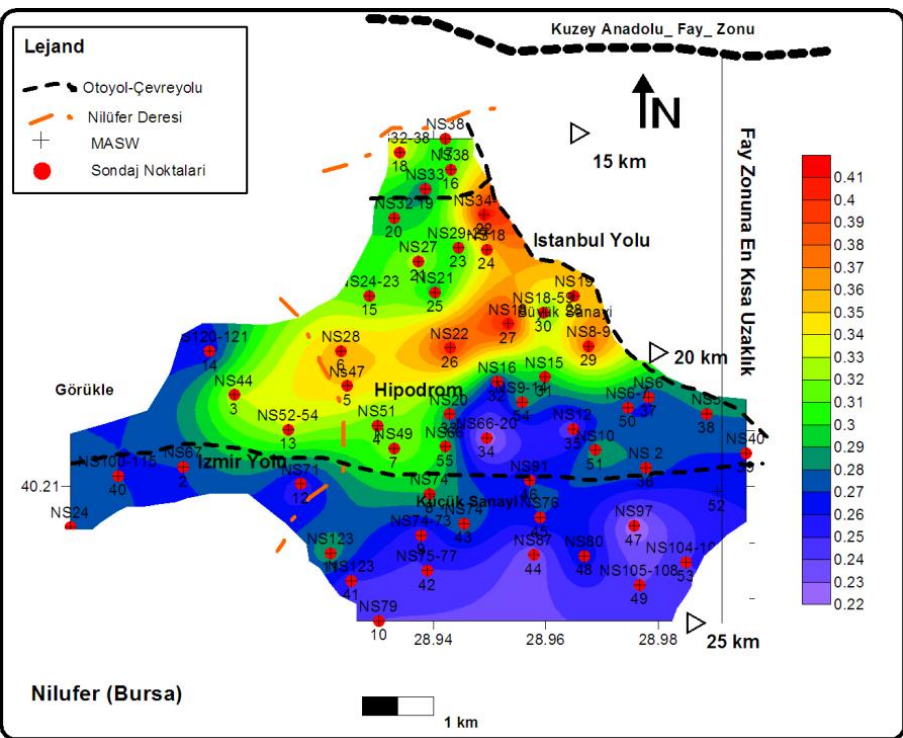

Figure 9 f. Spectral Acceleration Map with soil-earthquake interaction for $0.0 \mathrm{sec}$ period in Nilüfer

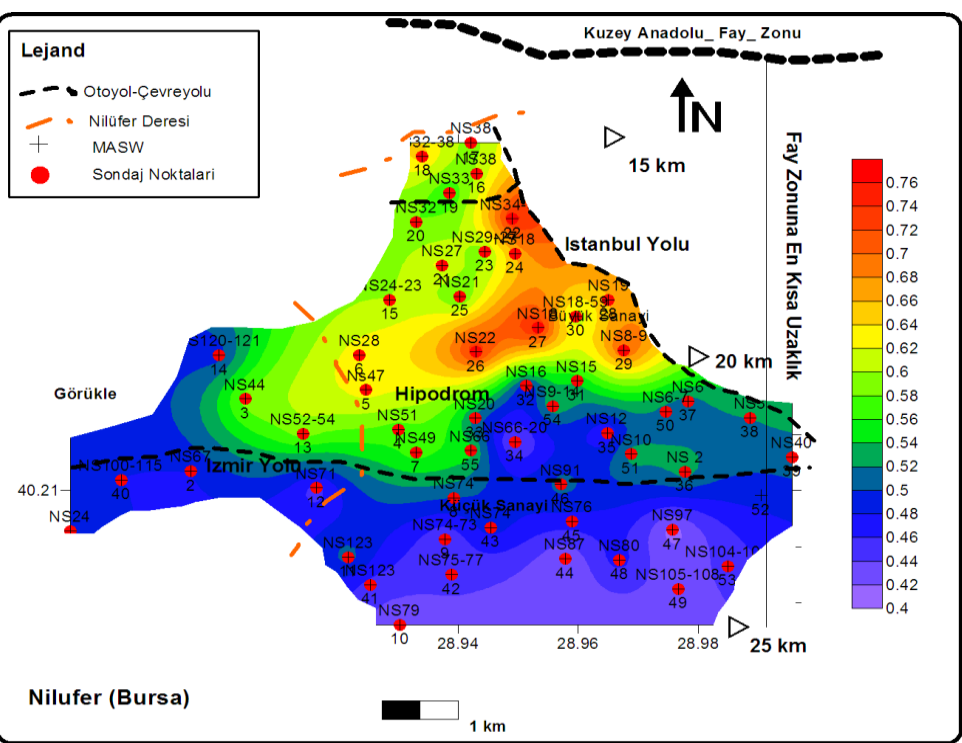

Figure 9 g. Spectral Acceleration Map with soil-earthquake interaction for $0.2 \mathrm{sec}$ period in Nilüfer (Bursa) District 


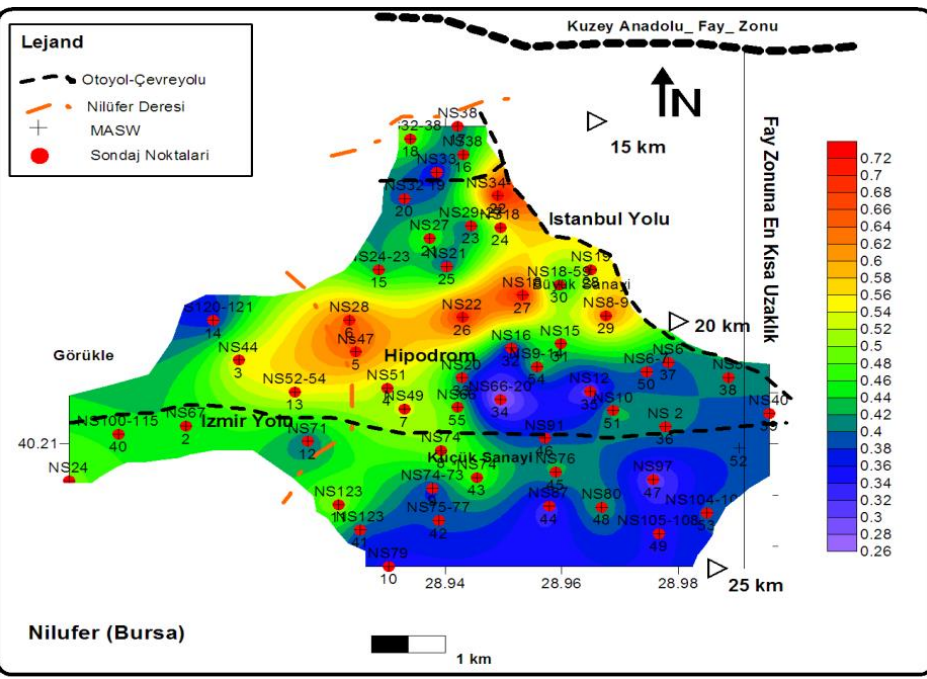

Figure 9 h. Spectral Acceleration Map with soil-earthquake interaction for $1.0 \mathrm{sec}$ period in Nilüfer (Bursa) District

\subsection{GEOTECHNICAL FACTORS}

The shear strength of a soil is the highest shear stress that can be applied to the soil mass. The shear stresses that cause the shear stress along the shearing plane are the highest shear stress that the soil can bear, hence the shear strength. Accordingly, the shear strength is the limit value. The shear strength is the value that corresponds to the plastic equilibrium state, that is, it has no return and is a failure condition. Shear strength on the soil is formed by two properties of the soil:

472 The important shear strength parameter of the soil is $\varphi$. Because it is a parameter that covers 473 the behaviour for general and all soils compared to c. Friction is caused by the soil grains that 474 are in contact with each other and the stress transfer between each other. The soil is a three475 phase environment. So, soils are the three components of water, air, soil particles. In the soil 
environment where these three components are mixed, the ratios of these components relative to each other are effective on soil behavior.

As geotechnical data for this study, over 200 boreholes (geotechnical) were provided from Bursa City Municipality. From this data, sand and silty sand units were extracted. Soil liquefaction analysis was performed based on geotechnical data. For this analysis, acceleration values (a: 0.40-0.45) and magnitude (M: 7.0-7.5) were selected. As a result, liquefaction analysis and liquefaction settlement analysis were estimated. Liquefaction Potential Index (PL) map is given according to several accelerations and magnitudes for Bursa (Osmangazi, Y1ldırım, , Gürsü, Kestel) districts in Figure 10a and 10b and a map of settlements related to liquefaction, for Bursa (Osmangazi, Yıldırım, , Gürsü, Kestel) city (a: 0.40-M: 7.0) is given in Figure 10c. For Nilufer district, the same maps were given in Figure 11a, b,c, d and e. The map of groundwater level for Nilufer district was given in Figure 12.

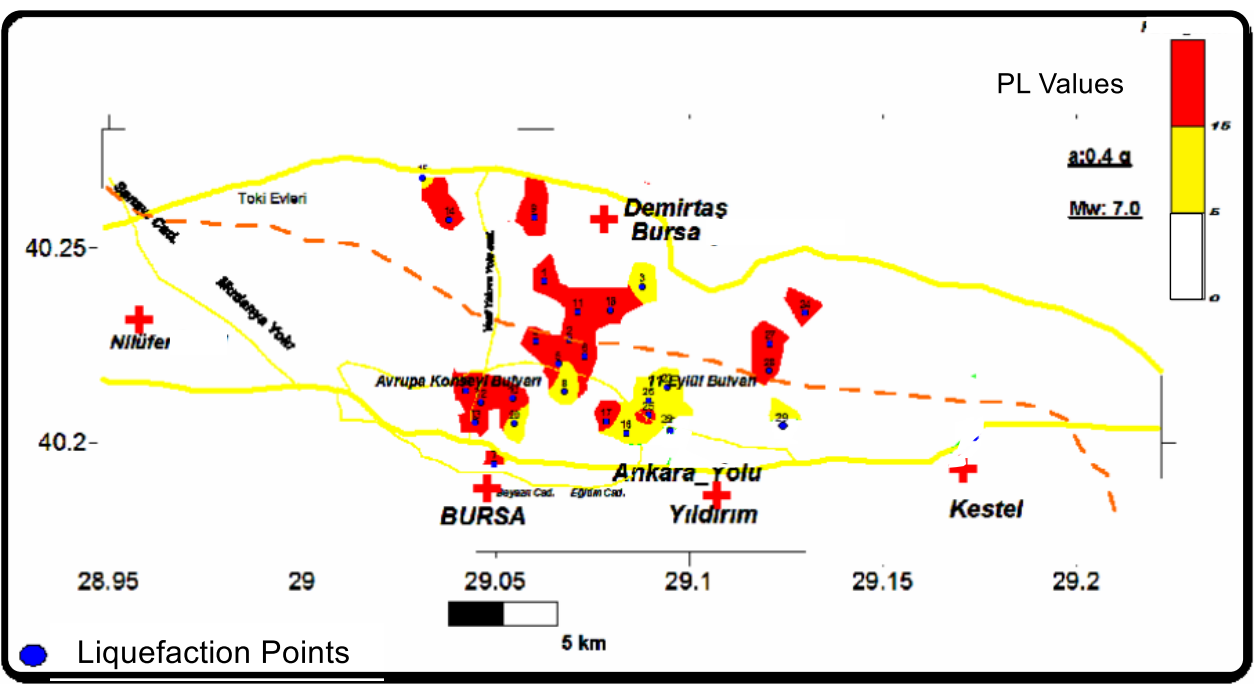

Figure 10a Liquefaction Potential Index (PL) map according to acceleration and magnitude (a: 0.40-M: 7.0) for Bursa (Osmangazi, Yıldırım, Gürsü, Kestel) city 


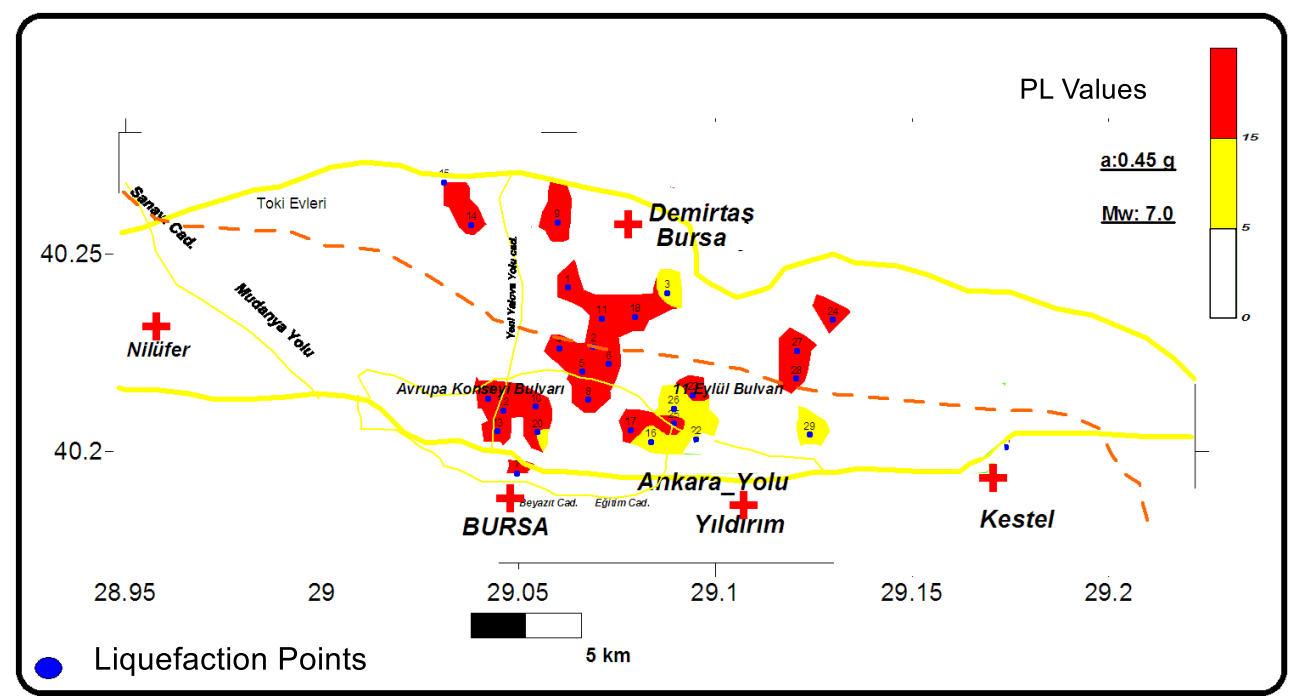

Figure 9b Liquefaction Potential Index (PL) map according to acceleration and magnitude (a:

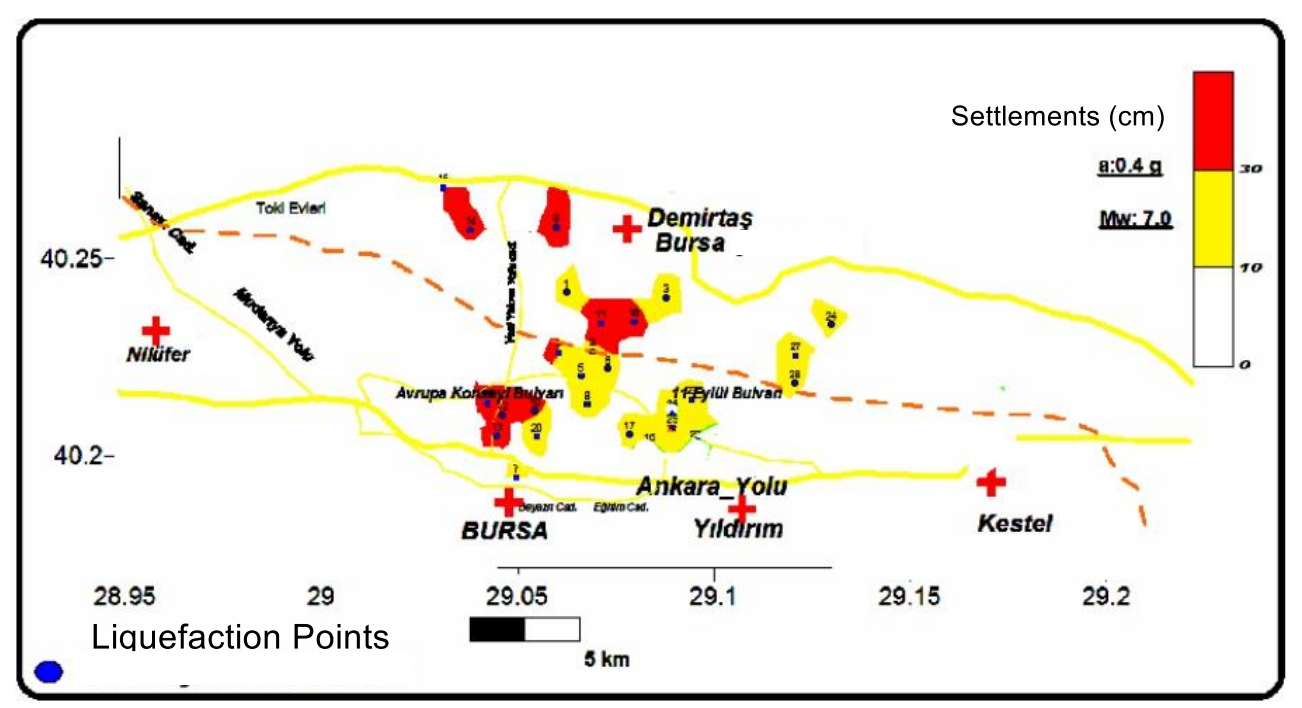


503 Figure 10c. Map of settlements related to liquefaction, for Bursa (Osmangazi, Y1ldırım, 504 Gürsü, Kestel) city (a: 0.40-M: 7.0).

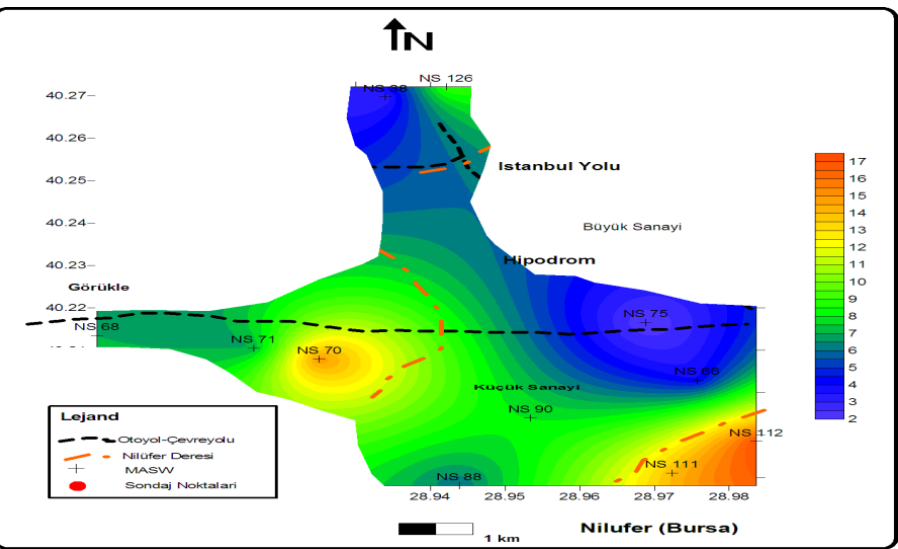

Figure 11a Liquefaction Potential Index (PL) map according to acceleration and magnitude (a: 0.45-M: 7.6) in Nilufer (Bursa) District.

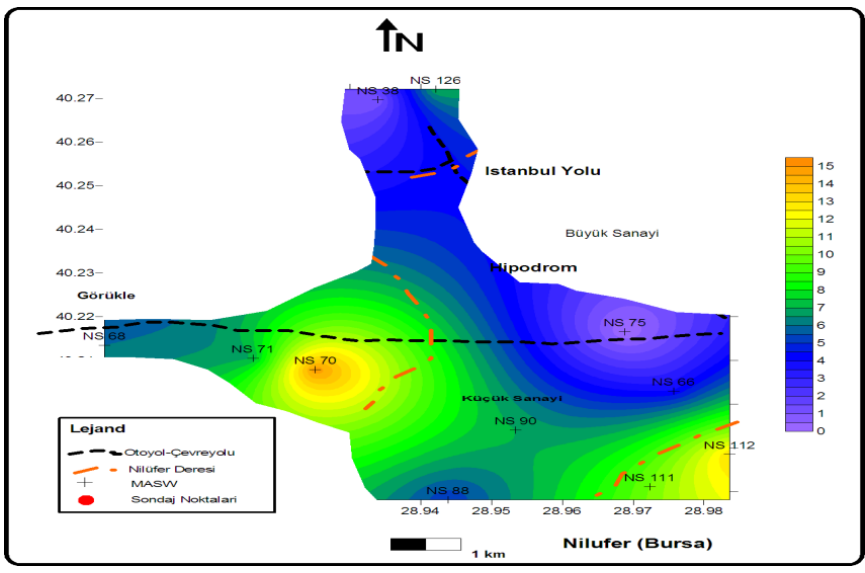

510 Figure 11b Liquefaction Potential Index (PL) map according to acceleration and magnitude (a: 0.40-M: 7.4) in Nilufer (Bursa) District. 
https://doi.org/10.5194/nhess-2020-301

Preprint. Discussion started: 8 October 2020

(c) Author(s) 2020. CC BY 4.0 License.
Natural Hazards and Earth System Sciences

Discussions

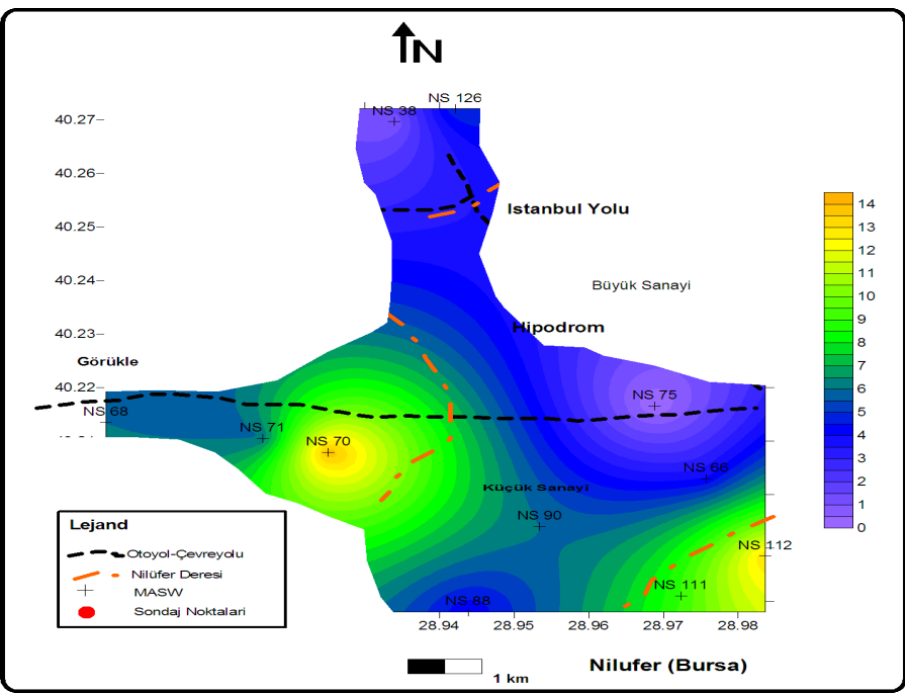

Figure 11c Liquefaction Potential Index (PL) map according to acceleration and magnitude (a: 0.40-M: 7.2) in Nilufer (Bursa) District.

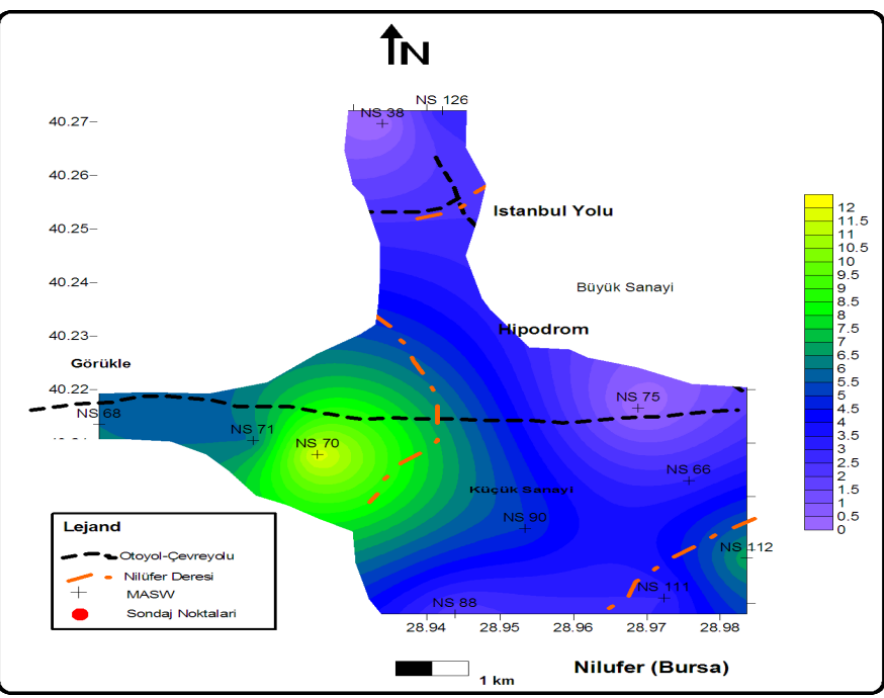

Figure 11d Liquefaction Potential Index (PL) map according to acceleration and magnitude (a: $0.35 \mathrm{M}: 7.0)$ in Nilufer (Bursa) District. 
https://doi.org/10.5194/nhess-2020-301

Preprint. Discussion started: 8 October 2020

(c) Author(s) 2020. CC BY 4.0 License.
Natural Hazards and Earth System Sciences

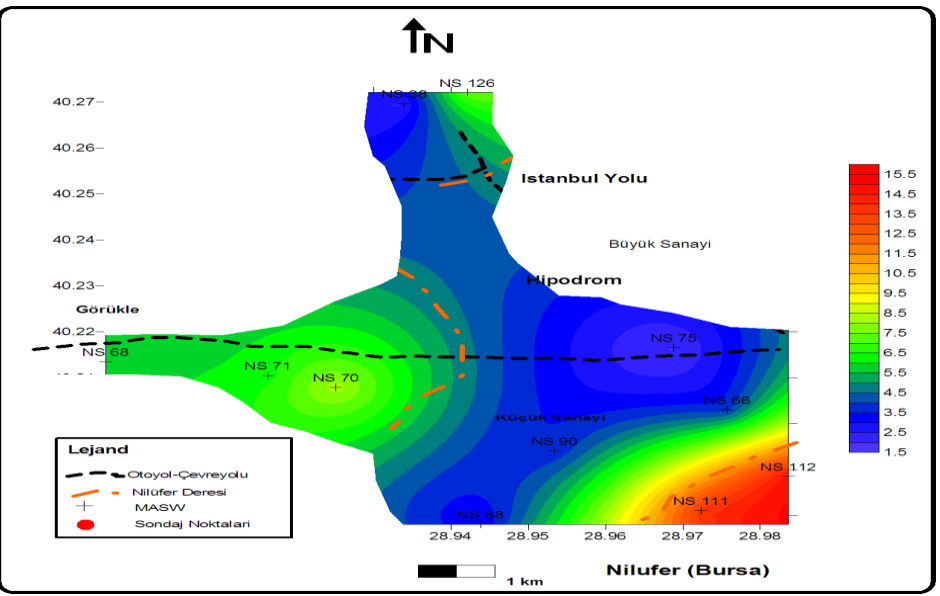

522 Figure 11f. Map of settlements related to liquefaction, in Nilufer (Bursa) District

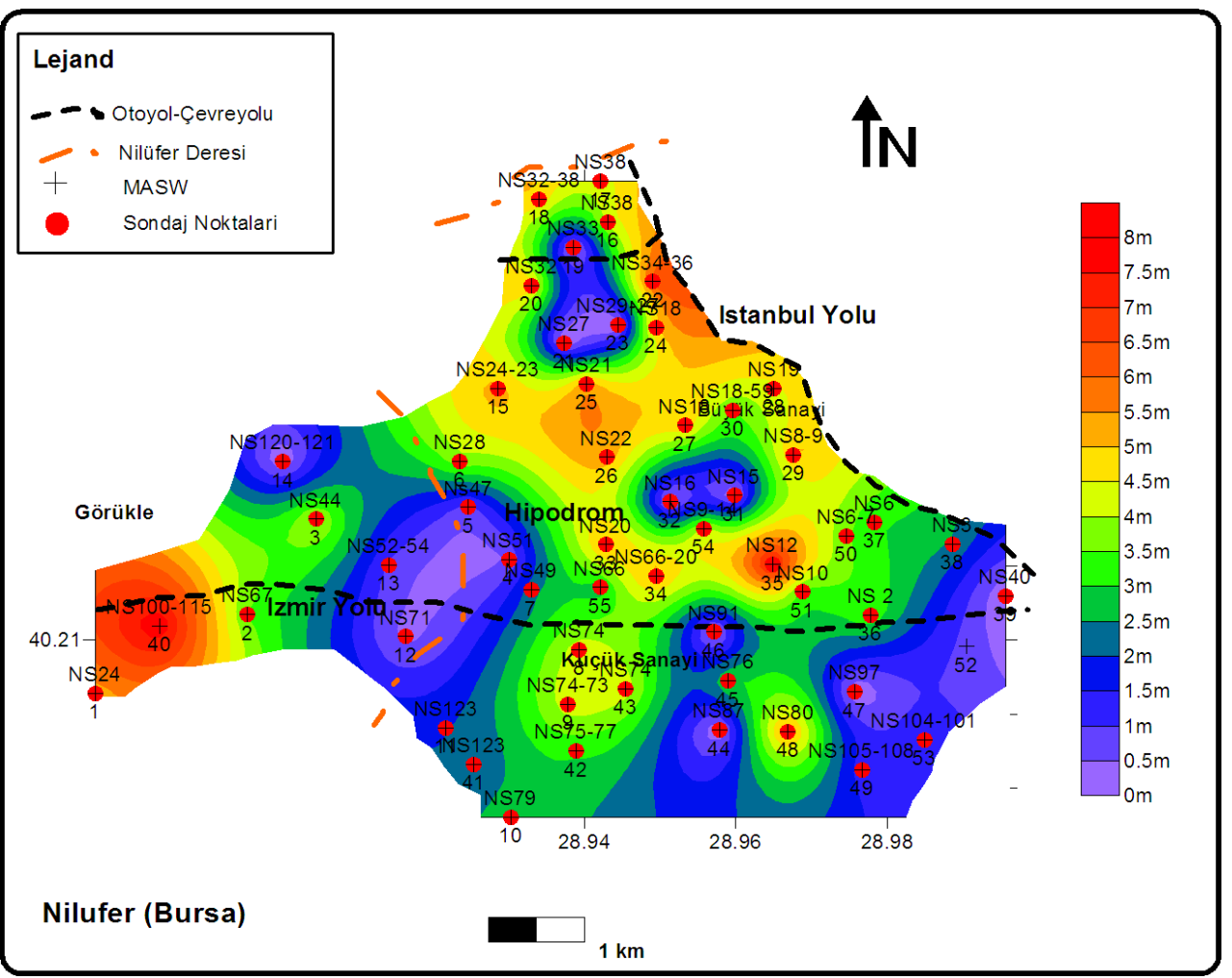

524 Figure 12. Map of Ground water level for Nilufer (Bursa) District 
526 Vs15 values was calculated from SPT Data and comparisons of real (MASW) geophysical 527 data. This and comparisons were given in Figure 13a and b.

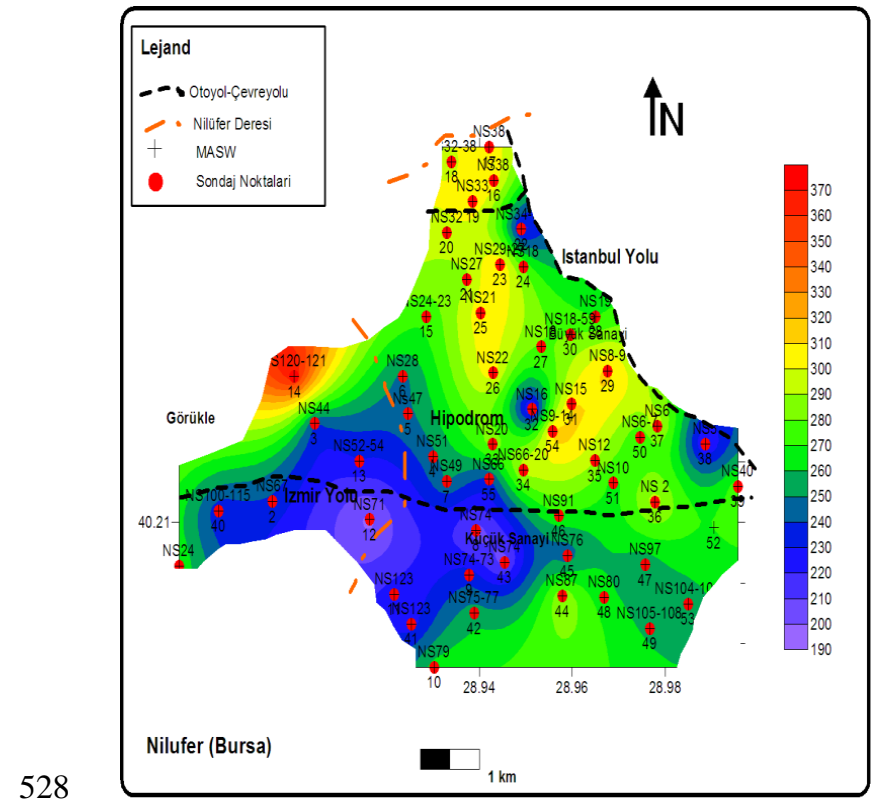

529 Figure 13 a. Vs15 values, estimated from SPT Data in Nilufer (Bursa) District 


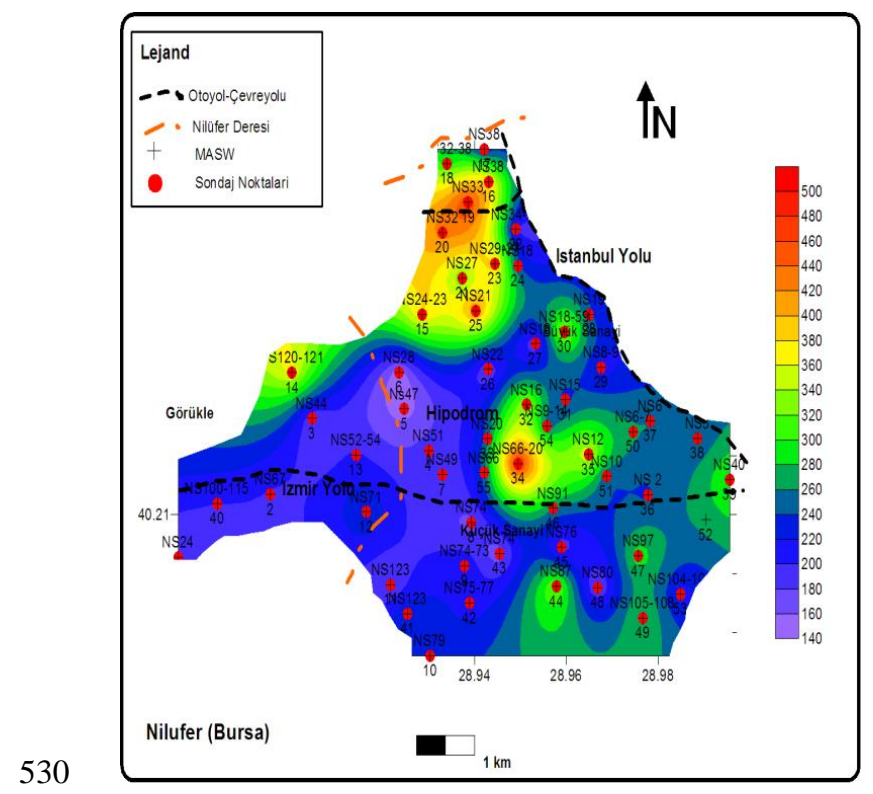

531 Figure 13b. Vs15 values, measured from Geophysical (MASW) Data in Nilufer (Bursa)

District

\subsection{Preparation of Seismic-Micro-Zonıng Map for Urban Plannıng}

534 As a result of the geophysical and geotechnical studies, a microzonation map was prepared

535 for a basis for urban planning (Figure 14a and b). As a result of the calculations, the hazard

536 level for Bursa city is classified into 3 categories. 


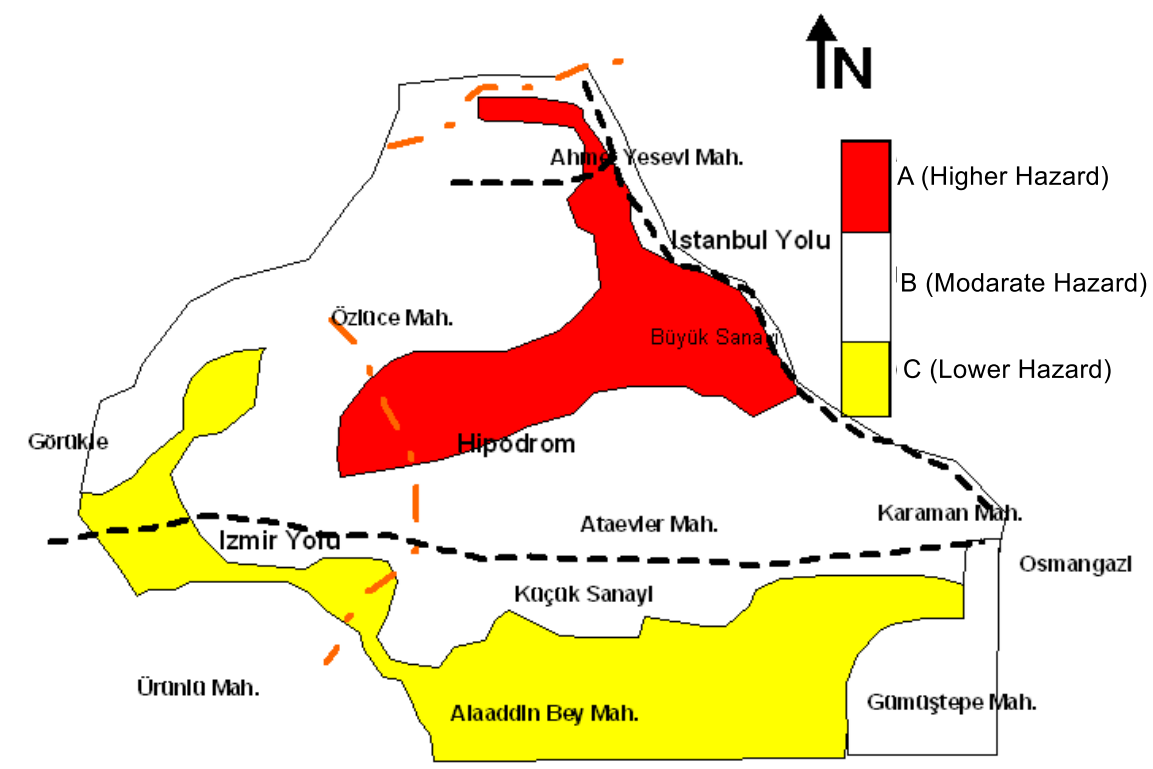

Microzonation Map of Nilufer Distirct

538 Figure 14a Microzonation map for a basis for urban planning in Bursa(Nillüfer) District

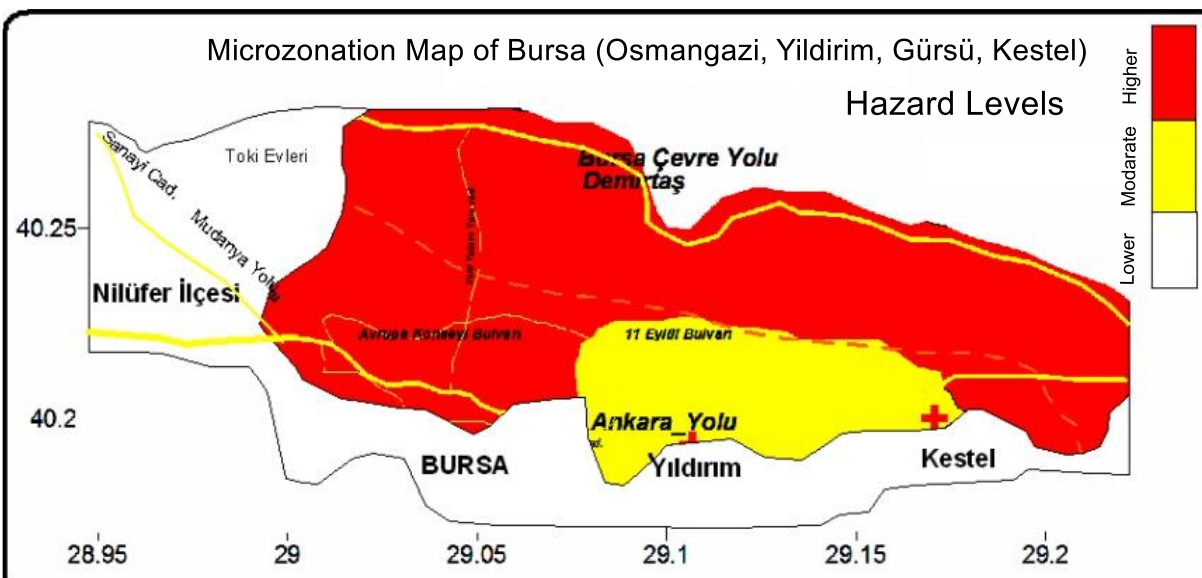

Figure 14b Microzonation map for a basis for urban planning in Bursa (Osmangaz, Yıldırım, 541 Gürsü, Kestel) Districts 


\section{RESULTS}

Geophysical measurements were made to estimate the shear wave velocity at 150 points in the study area by using the MASW method. The shear wave velocity map was prepared for the region. When we look at these maps, it was observed that Vs30, the type $\mathrm{C}$ type soils (According to NEERP) were dominant and the other parts were represented by the D-E type floors.

Earthquake hazard was determined probabilistically by using the Poison approach for the study area. In the probabilistic analysis, the magnitude of the project earthquake has been calculated for a certain time period for a certain exceeding rate. In the second phase of the study, soil liquefaction and possible settlements due to liquefaction were estimated and mapped by using geotechnical data. In the last phase, a final seismic microzonation map has been created. In this study, the main purpose is to reveal the use of geophysical and geotechnical data together in the context of microzonation.

In Bursa city, the levels of hazard for the problems that may occur interactively with the soils were determined in the event of an earthquake. In new studies to be carried out in the context of urban planning, urban transformation, and urban renewal, these hazard levels must be taken into consideration.

\section{Acknowledgement}

This study was supported reseach Unit of Istanbul Universitesi (Research Grant Number: YADOP-6708 and Thesis Project number: 5582)

\section{References}

- Abeki, A., Matsuda, I., Enomoto, T., Shigyo, V., Watanabe, K., Tanzawa, Y., Nakajima, Y., 1995, A study of seismic microzonation based on the dynamic 
charecteristics of Subsurface ground conditions, , Proc. 5th International Conference on Seismic Zonation, (3), 2187-2194.

- Astroza, M., Monge, J., 1991, Regional Seismic zonation in central Chili, Proc. 4th International Conference on Seismic Zonation, (3), 487-494.

- Aydemir, S.E., 1999, Türkiye'de İmar Kurumu, "Kentsel Alanların Planlanması Ve Tasarımı" Kitabında, (Ş.Aydemir, S.E. Aydemir, N.Ökten, A.M. Öksüz, C.Sancar, M.Özyaba), Karadeniz Teknik Üniveristesi Mühendislik Ve Mimarlık Fakültesi Ders Notlar1, No: 54, Trabzon.

- Beck, U., 1992, Risk Society: Towards a New Modernity. New Delhi: Sage. (Translated from the German Risikogesellschaft [1] published in 1986.

- Beck, U., 1999, World Risk Society, Cambridge: Polity.

- Bell, F.G., 1998, Environmental Geology, Blackwell, 594p.

- Bell; F.G., Crips, J.C., Culshaw, M.G., O’hara, M., 1987, Aspects of geology in planning, in: Culshaw, M.G., Bell; F.G., Crips, J.C., O’Hara, M., (eds.), Planning and Engineering geology, Geological Society Engineering geology Special pub. No:4, pp.1-38.

- $\quad$ Erdik, M., Ansal, A., Aydınoğlu, N., Barka, A., Işıkara, A.M., Yüzügüllü, Ö., Avcı, J., Özel, O., Alpay, Y., Birgören, G., 2000, İzmir Deprem Senaryosu ve Deprem Master Planı, İzmir Büyükşehir Belediyesi, (http://www.izmirbld.gov.tr/eski/izmirdeprem/izmirrapor.htm), İzmir.

- Ergünay, O., 1971, Türkiye'de Mikrozon çalışmaları ve Gediz kasabası uygulaması. İMO Teknik Bülteni, (8):115-128.

- Ergünay, O., 1973, Mikrobölgeleme. Deprem Araştırma Enstitüsü Bülteni, (2):10-31.

- Ergünay, O., 2002, Türkiye’nin Afet Yönetimi Sistemine Genel Bir Bakış : Sorunlar ve Çözümler, "Kentsel Yerleşmeler ve Doğal Afetler: Derleyen: Emine M. Komut" içinde, Sayfa 1-9, Mimarlar Odası UIA II. Bölge Çalşıma Programı, Ankara.

- Ergünay, O., 2006, Mikrobölgeleme Çalışmaları ve Afet Senaryoları, JICA-Içişleri Bakanlığı Belediye Elemanları için Düzenlenen Zarar Azaltma Eğitimi Kursu (18-22 Eylül 2006)

- Faccioli, E., Battıstella, C., Alemanı, P., Lo Prest1, D., T1bald1, A., 1991, Seismic microzoning and soil dynamics studies in San Salvador,12th ICSMFE, Rio de Jenerio, Brazil. 
- Faccioli, E., Pessina, V., 2001, The Catania Project: Earthquake damage scenerios for a high risk area in Mediterrean, CNR Gruppo Nazionale per la Difesa dai Terremoti, Roma, 225 pp.

- Fah, D., Rüttener, E., Noack, T., Kruspan, P., 1997, Microzonation of the city Basel, Jounal of Seismology, 1,87-102.

- Finn, W.D.L, 1991. Geotechnical Engineering Aspect Of Microzonation, Proc. Fourth Intern'1. Conf. On Seismic Zonation, Vol.1, Pp. 199-259.

- Gürkan, P., Ergünay, O., 2002, Deprem zararlarının Azaltılmasında Alan Kullanımı, “Kentsel Yerleşmeler ve Doğal Afetler: Derleyen: Emine M. Komut” içinde, Sayfa 19, Mimarlar Odası UIA II. Bölge Çalışma Programı, Ankara.

- ISSMFE, 1993, Manual For Zonation On Seismic Geotechnical Hazards, Published By Japanese Society Of Soil Mechanics And Foundation Enginering.

- ISSMGE/TC4 (1999) Manual for Zonation on Seismic Geotechnical Hazards, Technical Committee for Earthquake Geotechnical Engineering, The Japanese Geotechnical Society

- Jimenez MJ, Garcia-Fernadez M, Zonno G, Cella F (2000). Mapping Sol Effects In Barcelona, Spain, Through An Integrated Gis Environment, Soil Dynamics Earthquake Eng., 19: 289-301.

- Hake, S.S., 1987, A review of engineering geological and geotechnical aspects of town and country planning with particular reference to minerals and extractive processes, in: Culshaw, M.G., Bell; F.G., Crips, J.C., O’Hara, M., (eds.), Planning and Engineering geology, Geological Society Engineering geology Special pub. No:4, pp.53-58.

- Kozacı, H., Kiper, S., Gnçoğlu, S., Şişman, M., Yurdatapan, O., İşcan, A., Babaç, S., 1969, Kuyucak Sismik mikrozon etüd raporu, İmar ve iskan Bakanlığı, Afet İşleri Genel Müdürlüğü, Deprem Araştırma Ensitüsü, Ankara.

- Kozacı, H., 1970, Gediz deprem etüdü ve yeni Gediz yerleşme alanı mikrozon etüdleri, İmar ve iskan Bakanlığı, Afet İşleri Genel Müdürlüğü, Deprem Araştırma Enstitüsü, Ankara.

- Lasterico, R., Monge, J., 1972, Chilean Experience in seismic microzonation, Proc. International Conference on Microzonation, (1), 231-248.

- Le Pichon, X., Şengör, A. M. C., Demirbağ, E., Rangin, C., Imren, C., Armijo, R., Görür, N., Çağatay, N., Mercier de Lepinay, B., Meyer, B., Saatçılar, R., Tok, B. 
(2001). The active main Marmara fault. Earth and Planetary Science Letters, 192(4), 595-616.

- Legget, R.F., 1987, The value of geology in planning, in: Culshaw, M.G., Bell; F.G., Crips, J.C., O’Hara, M., (eds.), Planning and Engineering geology, Geological Society Engineering geology Special pub. No:4, pp.53-58.

- Lungu, D., Aldea, A., Cornea, T., Arıon, C., 2000, Seismic microzonation of the City of Bucharest, 6th International Conference on Seismic Zonation, California, US.

- Marcellini, A., Stucc1, M., Petrinı V., 1982, Some aspects of the microzonation of Ancona, Proc. 3rd International Earthquake Microzonation Conference; Universty of Washington Seatle, (3), 1475-1488.

- Marcellini, A., VD., 1998, Seismic microzonation of some municipalities of the area (Emilia-Romagna Region), Proc. 11th European Conference on Earthquake Engineering, A. Balkema Rotherdam.

- Nalkaya, S., (2006). Kentsel Dönüşüm ve Kent Kimliği, Yapı Dergisi, Yap1-Endüstri Merkezi Yayınları, 292, 39-43.

- Nigg, J., 1982. Microzonation And Public Preparedness: A Viable Approach, Proceedings Of The 3th International Earthquake Microzonation Conference, Seattle.

- Özçep, F., Karabulut, S., Alpaslan, N., Ceyhan, U., Gündoğdu, O., 2003, Deprem Zararlarının Azaltılması İçin Kent / Bölge Planlama Sürecinde Mikrobölgeleme Çalışmaları, Kocaeli 2003 Deprem Sempozyumu, Sunular, Sayfa: 477-486, Kocaeli Üniversitesi, Kasım 2003, Kocaeli.

- Ozcep, F., Zarif, H., 2006, Microzonation Studies based on Soil Liquefaction: Yalova City (Turkey), First European Conference on Earthquake Engineering and Seismology, Abstract Book, pp. 348..

- Korkmaz, B., Ozcep, F., 2010, Fast and Efficient Use of Geophysical and Geotechnical Data in Urban Microzonation Studies At Small Scales : Using Sisli (Istanbul) As Example, International Journal of Physical Sciences Vol. 5 (2), pp. 158 169.

- Ozcep, F., Karabulut, S., Korkmaz, B., Zarif, H., 2010, Seismic Microzonation Studies in Sisli / Istanbul (Turkey), Scientific Research and Essay, 4 July 2010; 5(13), pp. $1595-1614$. 
- Ozcep, F., 2010, SoilEngineering: a Microsofts Excel ${ }^{\circledR}$ Spreadsheet $\odot$ Program for Geotechnical and Geophysical Analysis of Soils, Computers \& Geosciences, Volume 36, Issue 10, October 2010, Pages 1355-1361.

- Park CB, Miller RD, Xia J (1999). Multichannel analysis of surface Waves (Masw); Geophys., 64: 800-8.

- Park CB, Miller RD, Xia J, Ivanov J (2007). Multichannel Analysis fo Surface waves (MASW) - active and passive methods, The leading edge. pp. 60-64

- Sharma, S. And Kovacs, W.D., 1980, Microzonation Of Memphis, Tennessee Area, A Report On Research Sponsored By The Usgs, No: 14.08.0001-17752.

- Shane III, O. C. and Küçük, M., 1998, The World's First City, Archaeology, Volume 51 Number 2, March/April.

- Tabban, A., 1972, Gediz merkezinin gözlemlere dayanılarak mikrozon etüdieri: Türkiye Ulusal Geodezi ve Geofizik Birliği, Mos. 15-30 .

- Tokay, M., Doyuran, V., 1979, Eski Gediz Kentinde Mikro - Bölgelendirme Çalışmaları; Türkiye Jeoloji Kurumu Bülteni, Turkey, V. 22, 211 - 214.

- Wenzel, F., Bendimerad, F., 2004, Megacities and Megarisks, Earthquakes and Megacities Inititives, Workshop an Risk Science, Society and Sustainable Development, Stocholm, İndirilme Tarihi: 06.01.2007, Web Sayfas1 : http://iugg-georisk.org/presentations/Wenzel/wenzel_st04/frame2.htm

- Yılmaz, Ö., Eser, M., Berilgen, M., 2003, Sismik Mikrozonlamaya Mahsus Entegre Sismik ve Geoteknik İnceleme, Kocaeli 2003 Deprem Sempozyumu, Kocaeli Üniversitesi, Kasım 2003, Kocaeli.

- Zarif, H., Özçep, F., Asçı, M., 2006, Microzonation Studies based on Soil Liquefaction: Yalova and Izmit (Turkey) Cities, EGU General Assembly 2006,Wien, Austria.

- ZETAŞ, 2000, Bursa Büyükşehir Belediye Başkanlığı Osmangazi, Yıldırım, Nilüfer İlçesi Zemin Etüdleri Ve Temel Mühendisliği Değerlendirme Raporu, ZETAŞ Zemin Teknolojisi AŞ, İstanbul. 